\title{
Vector-borne diseases in Brazil: climate change and future global warming scenarios
}

\author{
Doenças transmitidas por vetores no Brasil: mudanças \\ climáticas e cenários futuros de aquecimento global
}

Bruno Moreira de Carvalho ${ }^{a}$

Letícia Palazzi Perez

Beatriz Fátima Alves de Oliveirac

Ludmila da Silva Viana Jacobson ${ }^{d}$

Marco Aurélio Horta ${ }^{\mathrm{e}}$

Andréa Sobral ${ }^{\mathrm{f}}$

Sandra de Souza Hacon ${ }^{g}$

a Postdoctoral fellow at the Barcelona Institute for Global Health, Barcelona, Spain brunomc.eco@gmail.com

${ }^{b}$ Visiting professor at the Federal University of Paraiba (UFPB), Department of Architecture and Urbanism, João Pessoa, PB, Brasil Leticia.palazzi@gmail.com

' Doctor in Sciences by the Sério Arouca National Public Health School (ENSP/FIOCRUZ), Oswaldo Cruz Foundation Regional Office in the state of Piauí, Teresina, Pl, Brazil

E-mail: beatrizenf@gmail.com

${ }^{d}$ Doctor in Collective Health by the Social Medicine Institute, (IMS/UERJ), Universidade do Federal Fluminense (UFF), Niterói, RJ, Brazil E-mail: ludmillaviana@yahoo.com.br

${ }^{e}$ Doctor in National Public Health and Environment by the National Public Health School (ENSP) FIOCRUZ), Oswaldo Cruz Foundation, and researcher in public health at the Oswaldo Cruz Institute, Rio de Janeiro, RJ, Brasil E-mail: marcohorta@yahoo.com

${ }^{f}$ Samuel Pessoa Department of Endemics of the National School of Public Health ENSP Oswaldo Cruz Foundation - FIOCRUZ, Rio de Janeiro, RJ, Brasil E-mail: asasobral@gmail.com

${ }^{g}$ Doctor in Biosciences by the Federal Fluminense University (UFF), National School on Public Health (ENSP/FIOCRUZ), Rio de Janeiro, RJ, Brazil E-mail: shacon@ensp.fiocruz.br 
Data and results presented in this article were developed under the project of the "Fourth National Communication and Biennial Update Reports of Brazil to the Climate Convention", coordinated by the Ministry of Science, Technology and Innovations, with the support of the United Nations Development Programme and resources of the Global Environment Facility, to which we offer our thanks.

\section{ABSTRACT}

Climate change affects human health either directly or indirectly, and related impacts are complex, non-linear, and depend on several variables. The various climate change impacts on health include a change in the spatial distribution of vector-borne diseases. In this regard, this study presents and discusses changes in the spatial distribution of climate suitability for visceral leishmaniasis, yellow fever and malaria in Brazil, in different global warming scenarios. Maximum entropy (MaxEnt) was used to construct climate suitability models in warming scenarios. Models were based in climate variables generated by the Eta-HadGEM2 ES regional model, in the baseline period 1965-2005 and RCP8.5 scenario, representing global warming levels of 1,5ㅇ (2011-2040), 2,0ㅇ (2041-2070) and 4,0ㄷ (20712099). The three diseases studied are largely influenced by climate and showed different distribution patterns within the country. In global warming scenarios, visceral leishmaniasis found more favorable climate conditions in the Southeastern and Southern regions of Brazil, while climate in the Northern and Center-West regions gradually became more favorable to yellow fever. In malaria scenarios, an increase in favorable climate conditions to its high incidence was observed in the Atlantic Forest, where currently extra-Amazonian cases occur. The scenarios presented herein represent different possible consequences for the health sector in terms of adopting (or not) different measures to mitigate climate change in Brazil, such as reducing the emission of greenhouse gases.

Keywords: Global warming; Public health; Visceral leishmaniasis; Yellow fever, Malaria.

\section{RESUMO}

As mudanças climáticas afetam a saúde humana direta ou indiretamente, e seus impactos são complexos, não lineares e dependentes de diversas variáveis. Entre os diversos impactos das mudanças climáticas na saúde estão a alteração na distribuição espacial de doenças transmitidas por vetores. Nesse sentido, o presente estudo apresenta e discute mudanças na distribuição espacial da adequabilidade climática para leishmaniose visceral, febre amarela e malária no Brasil, em diferentes cenários de aquecimento global. Para a construção dos modelos de adequabilidade climática nos cenários de aquecimento, foi utilizado o algoritmo de máxima entropia (MaxEnt). Os modelos foram baseados em variáveis climáticas geradas pelo modelo climático regionalizado Eta-HadGEM2 ES, no período baseline (19652005) e no cenário RCP 8.5, representando os níveis de aquecimento global de 1,5ㄷ (2011-2040), 2,0C (2041-2070) e 4,0C (2071-2099). As três doenças estudadas são amplamente influenciadas pelo clima e apresentaram diferentes padrões de distribuição no País. Em cenários de aquecimento global, a leishmaniose visceral apresentou condições climáticas mais favoráveis à sua ocorrência nas regiões Sudeste e Sul do Brasil, enquanto o clima nas regiões Norte e Centro-Oeste se tornou gradativamente mais adequado para febre amarela. Nos cenários para malária foi observado aumento nas condições climáticas favoráveis à sua alta incidência na Mata Atlântica, onde atualmente ocorrem casos extraamazônicos. Os cenários aqui apresentados representam diferentes consequências possíveis para o setor de saúde e da adoção ou não de diferentes medidas para mitigar as mudanças climáticas no Brasil, como a redução da emissão de gases de efeito estufa.

Palavras-chave: Aquecimento global. Saúde Pública. Leishmaniose Visceral. Febre Amarela. Malária. 


\section{INTRODUCTION}

Climate change may affect human health either directly or indirectly, and related impacts may be aggravated by socio-environmental vulnerability (BARCELLOS et al., 2009). Direct impacts are those primarily associated with the occurrence of extreme events, i.e., heat waves, extreme cold, droughts and more intense rain regimes.

Indirect impacts are mediated by ecosystem, biodiversity and hydrological/biogeochemical imbalances that influence morbidity and mortality profiles (BARCELLOS et al., 2009; IPCC, 2014). Among the effects generated socially in response to climate change are those related to economic changes, which may result in occupational impacts, malnutrition, psychosocial problems and forced migration (BENNETT et al., 2014), in addition to those related to health system capacity and socioeconomic conditions of the population (BARCELLOS et al., 2009; HACON et al., 2018). Although didactically classified, the climate change impacts on human health are complex, multi-factorial and non-linear. Thus, they may be enhanced or minimized depending on the characteristics of the individual and collective social determinants inherent to a given social organization and their interrelationships with the physical environment (HACON et al., 2018).

Among the diseases with indirect impact, vector-borne diseases are a concern in the global health sector: malaria is responsible for causing more than 400 thousand deaths annually worldwide, of which two thirds occur in children under 5 years of age (WORLD HEALTH ORGANIZATION, 2019); dengue fever cases have been progressively increasing in recent decades (CASTRO; WILSON; BLOOM, 2017); the global expansion of invasive mosquitoes, facilitated by the international transport of materials and products, has been linked to the emergence of new sources of arboviruses transmission (BENEDICT et al., 2007).

In the current Brazilian epidemiological scenario, malaria, Chagas disease, leishmaniasis, dengue fever, yellow fever, the Oroupouche virus, Mayaro virus, filariasis (bancrofti and onchocerciasis), West Nile virus, among others, stand out. Some of these diseases are broadly distributed in the country, i.e., dengue fever, while others have regional characteristics, such as the Oroupoche virus in the Amazon (BARCELLOS et al., 2009). In addition to this scenario, the recent outbreak of zika and chikungunya viruses have further aggravated the epidemiological situation of these diseases across the national territory (CAMPOS; BANDEIRA; SARDI, 2015; ZANLUCA et al., 2015), affecting mainly the Southeastern, Northeastern and Center-West regions (VASCONCELOS; PINHO, 2017).

Multiple factors can influence the dynamics of vector-borne diseases, such as environmental, sociodemographic, biological (life cycle of vectors) and health factors (population susceptibility, governance, health systems and disease control programs) (GRACIE et al., 2014). Disorderly urbanization also impacts the transmission dynamics, with informal and precarious settlements generally without access to basic sanitation services, such as water distribution networks and sewage collection (MARICATO, 2009), in addition to the unavailability of environmental sanitation services, such as rainwater galleries and adequate waste collection (FOURNET et al., 2018).

Among the environmental factors, climate variables are important components in the time and spatial distribution of vector-borne diseases, both limiting their spread and influencing transmission dynamics (HORTA et al., 2014). Climate change can lead to changes in spatial distribution, population density, seasonality, prevalence of infection, parasitic load or even in the adaptation of the vector and host species to new transmission cycles (KOVATS et al., 2001; MILLS; GAGE; KHAN, 2010)a change in climate would be expected to cause changes in the geographical range, seasonality (intra-annual variability.

Temperature is an important factor that may slow down or accelerate the development or survival of insect vectors, as well as the extrinsic incubation period (EIP) of some pathogens (ALTO; JULIANO, 2001; BESERRA et al., 2009; HLAVACOVA; VOTYPKA; VOLF, 2013; RIVAS et al., 2014). Rainfall patterns 
have short and medium term effects on vector population dynamics, as they regulate the availability of breeding sites (ALTO; JULIANO, 2001; VALDEZ; SIBONA; CONDAT, 2018). Therefore, knowing the climate conditions that are favorable to vector development allows for anticipating annual generation cycles and times of major occurrence in infestation areas (KOVATS et al., 2001; MILLS; GAGE; KHAN, 2010; VALDEZ; SIBONA; CONDAT, 2018).

In the past few decades, studies and analyzes of increased global temperature impacts on human health have focused on retrospective case studies, such as the heat waves that hit Europe in 2003 and Russia in 2010, causing increases in mortality (MATSUEDA, 2011; ROBINE et al., 2008). Other studies have been conducted in several countries in order to assess the exposure-response relationship, establishing the relative risk between temperature and mortality (GASPARRINI et al., 2015; KINGSLEY et al., 2016).

In Brazil, some studies have delved into the relationship between the time and spatial distribution of vector-borne diseases and climate conditions (CARDOSO-LEITE et al., 2014; CARVALHO et al., 2015; DA COSTA; CORDEIRO; RANGEL, 2018; GURGEL-GONÇALVES et al., 2012; LAPORTA et al., 2011, 2015). However, few studies focused on the distribution of human cases of these diseases, aiming at generating scenarios of the impacts caused by climate change (CAMINADE et al., 2014; CARVALHO; RANGEL; VALE, 2017; LAPORTA et al., 2015; MENDES et al., 2016). In order to fill part of this gap, the present study includes analyzes of three vector-borne diseases of current relevance for Brazil, that present a wellknown relationship with climate variables: visceral leishmaniasis, yellow fever and malaria.

In Brazil, visceral leishmaniasis (VL) is transmitted by the bite of female sand fly Lutzomyia longipalpis infected by Leishmania infantum (BRASIL, 2014). A large number of wild and domestic mammal species, including the domestic dog, can host this parasite. According to the Ministry of Health's Notifiable Diseases Information System (SINAN for its acronym in Portuguese), the disease currently causes about 3,000-3,500 cases per year in the country, representing the highest rates in all of America (ALVAR et al., 2012; BRASIL, 2020a). VL is currently undergoing a process of geographic expansion and urbanization, with cases reported in capitals like Campo Grande, Belo Horizonte and Rio de Janeiro (BRASIL, 2014, 2020a). This process is associated with environmental changes, human migration, socioeconomic conditions and vector adaptation to peridomestic conditions (RANGEL et al., 2018; SALOMÓN et al., 2015). Occurrence and incidence of VL are modulated by climate, through interactions with the density of vectors and their seasonality (READY, 2008).

Lab experiments conducted from the colonization of the L. longipalpis vector demonstrated that higher temperatures caused an increase in its locomotor activity, which suggests that the vector populations would be more abundant in warmer seasons (RIVAS et al., 2014). Higher temperatures also accelerate the development of promastigote forms of Leishmania in L. Iongipalpis (HLAVACOVA; VOTYPKA; VOLF, 2013). Climate suitability models for this same vector species have demonstrated the likely expansion of its geographic distribution within the country in climate change scenarios, especially in eastern Amazon (PETERSON et al., 2017).

Yellow fever (YF) is a non-contagious infection that remains endemic or enzootic in the tropical forests of America and Africa, periodically causing isolated outbreaks or epidemics of greater or lesser impact on public health. It is caused by an arbovirus of the genus Flavivirus, has non-human primates as hosts, and it is transmitted by mosquitos of the genera Haemagogus and Sabethes (in the wild cycle) and Aedes aegypti (in the urban cycle) (VASCONCELOS, 2003). Sylvatic yellow fever is an endemic disease in the Amazon region. From time to time, the virus reappears in the extra-Amazonian region, with outbreaks of varying magnitude and spatial distribution, expanding to areas of viral circulation that may affect as far as the Southern region of the country. Occurrence is seasonal, with a greater incidence from December to May, when the high temperatures and rainfall favor high vector density (BRASIL, 2020b).

Epizootics (mortality of non-human primates by YF) usually precede the disease in humans, being sentinel events for the early detection of outbreaks. The recent YF reemergence in Brazil, which started 
in 2014, affected the metropolitan regions of a number of states and caused unprecedented impacts in the recent history of the disease. The major outbreaks in the history of YF in Brazil since its transmission cycle was first described in the 1930s happened in the monitoring years 2016/2017 and 2017/2018, when some 2,100 cases were recorded and more than 700 people were killed by the disease (BRASIL, 2020b). A recent study reported that climate variables contributed with some $60 \%$ for the occurrence of YF in southern Brazil (DE ALMEIDA et al., 2019).

Malaria is an infectious disease caused by protozoa of the genus Plasmodium and transmitted by vector mosquitoes of the Anophelinae subfamily, that represents a significant burden of diseases at the global and regional level, and whose occurrence and transmission are related to climate conditions (CAMINADE et al., 2014; PARHAM; MICHAEL, 2010). Changes in temperature and rainfall, combined with changes in ecosystems, may affect the spatial distribution and the intensity of malaria occurrence, which is a complex and multi-factorial disease, and an understanding of its association with climate is essential for Brazil.

Recent evidence suggests that the incidence of malaria is increasing in the world's coldest regions due to global warming (CELLA et al., 2019). Babaie et al. (2018) suggest that temperature, rainfall, relativity humidity, and intensity and direction of the wind are the most important climate factors for growth and proliferation of Anopheles, the life cycle of Plasmodium and malaria prevalence. Despite the fact that its main vector in Brazil, Anopheles darlingi, is widely distributed, malaria is basically restricted to Amazonian municipalities (HACON et al., 2018)including the environmental impact assessment (EIA. Extra-Amazonian malaria occurs sporadically in the country, mainly in regions of the Atlantic Forest where anophelines of the Kerteszia group are responsible for transmission. Previous studies on climate suitability modeling for malaria in Brazil have pointed to the likely expansion of areas suitable for Plasmodium falciparum in climate change scenarios (LAPORTA et al., 2015).

Considering that these diseases occur under certain climate conditions, this study aimed at mapping the favorable climate space to their occurrence in global warming scenarios. This climate space was characterized by mathematical models that estimate climate suitability - a numerical representation of how suitable the climate of the study area is for the occurrence of those diseases (PETERSON, 2006; PETERSON et al., 2011). Locations where visceral leishmaniasis, yellow fever and malaria occur were associated with climate variables in the baseline period 2000-2010. Later climate suitability projections for those diseases were generated in climate change scenarios that represent global warming levels selected by the Paris Agreement in December 2015 (1.5으, 2.0ㄷ and 4.0ㄷ) (IPCC, 2018).

\section{MATERIAL AND METHODS}

In order to relate the occurrence of vector diseases to climate variables, ecological niche modeling was used. This methodology is used in biodiversity studies (GUISAN; ZIMMERMANN, 2000; PETERSON et al., 2011; RANDIN et al., 2020)the development of predictive habitat distribution models has rapidly increased in ecology. Such models are static and probabilistic in nature, since they statistically relate the geographical distribution of species or communities to their present environment. A wide array of models has been developed to cover aspects as diverse as biogeography, conservation biology, climate change research, and habitat or species management. In this paper, we present a review of predictive habitat distribution modeling. The variety of statistical techniques used is growing. Ordinary multiple regression and its generalized form (GLM and has recently been applied to Epidemiology, Public Health and species distribution studies (ALKISHE et al., 2020; ARTUN, 2019; CARVALHO; RANGEL; VALE, 2017; LIPPI et al., 2019). These models, also referred to in the literature as environmental suitability or species distribution models (PETERSON; SOBERÓN, 2012), are based on the ecological niche theory to relate the abiotic factors that define the species geographic distribution (GUISAN; ZIMMERMANN, 2000; PETERSON et al., 2011). 
There are two basic approaches to apply an ecological niche model to infectious diseases transmission (PETERSON, 2006; PETERSON et al., 2011). The first is to model species in the transmission cycle individually, providing the opportunity to find different reasons for the presence or absence of disease transmission in the study area. The second approach takes into consideration the entire transmission cycle and its ecological relationships as a "black box", and analyzes the disease geographical distribution, as if it were a species (ARBOLEDA; JARAMILLO-O.; PETERSON, 2009; ARTUN, 2019; NIETO; MALONE; BAVIA, 2006; YÉ et al., 2007). This approach indirectly gathers all species that are part of the transmission cycle, as well as their environmental needs and ecological interactions.

In this study, the second approach was chosen, as the objective was to characterize the climate space occupied by the occurrence of diseases in humans, and thus be able to generate scenarios on climate change impacts on their spatial distribution. Thus, the study was based on the application of the MaxEnt machine learning algorithm (PHILLIPS; ANDERSON; SCHAPIRE, 2006)together with inexpensive and powerful computers, has fueled a rapid increase in predictive modeling of species environmental requirements and geographic distributions. For some species, detailed presence/absence occurrence data are available, allowing the use of a variety of standard statistical techniques. However, absence data are not available for most species. In this paper, we introduce the use of the maximum entropy method (Maxent to associate disease occurrence points with climate variables, and then map climate suitability areas across the study area (Brazil) and in different scenarios (Figure 1).

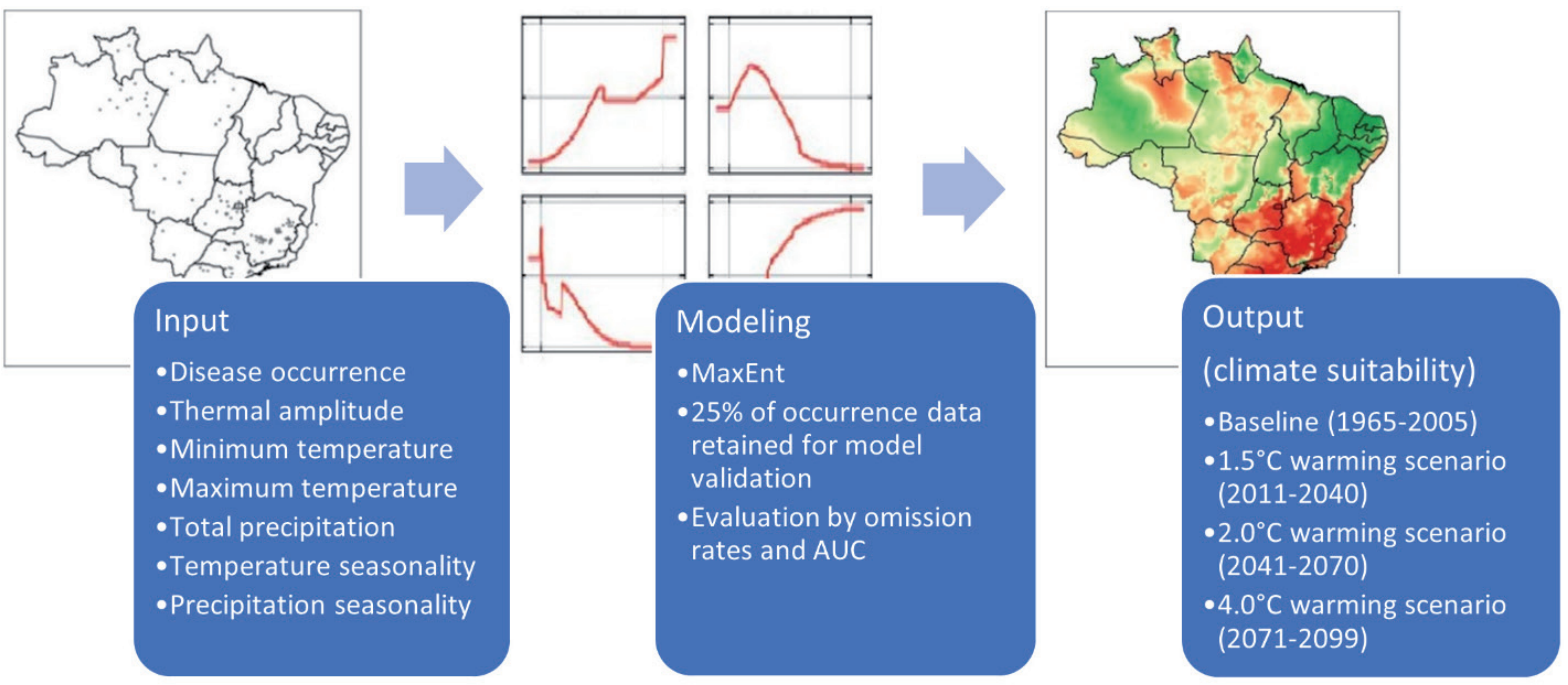

Figure 1 | Synthesis of the ecological niche modeling methodology applied in this study: Input data were occurrence points of vector-borne diseases and climate variables related to temperature and rainfall. The algorithm used for modeling was MaxEnt. Models were then projected for the baseline period and different climate change scenarios.

Source: Prepared by the authors.

\subsection{CLIMATE DATA}

The study was based on the IPCC (Intergovernmental Panel on Climate Change) projections with future Earth climate scenarios according to the levels of greenhouse gas (GHG) emissions through the Representative Concentration Pathways - RCP. The variables minimum temperature, maximum temperature, thermal amplitude and total precipitation were extracted from the Eta-Hadgem2 ES regional model (CHOU et al., 2014)Regional Climate Models (RCMs, for the period 1965-2005 and in three time intervals of the RCP8.5 scenario: 2011-2040, 2041-2070 and 2071-2099. These represent global warming levels of $1.5^{\circ} \mathrm{C}, 2.0^{\circ} \mathrm{C}$ e $4.0^{\circ} \mathrm{C}$, respectively, of the Paris Agreement (IPCC, 2018). 
In order to generate more biologically significant variables, the monthly temperature and precipitation values were used to calculate 19 bioclimatic variables (FICK; HIJMANS, 2017). These are often used in ecological studies, species distribution modeling, and ecological niche modeling (FICK; HIJMANS, 2017). Bioclimatic variables represent annual trends (i.e., annual average temperature, annual precipitation), seasonality (i.e., annual temperature and precipitation variation) and extreme or limiting environmental factors (i.e., coldest and warmest month temperature and precipitation of the driest quarter).

All the climate variables were obtained and spatially standardized for the Brazil extension in the native spatial resolution of the Eta-HADGEM2 ES model (approx. 20km). In order to reduce the collinearity among the variables, those with Pearson's correlation above 0.9 were excluded from the selection. Therefore, the final set of variables used in the models were composed by: thermal amplitude, minimum temperature, maximum temperature, total precipitation, temperature seasonality and precipitation seasonality.

\subsection{EPIDEMIOLOGIC DATA}

Numbers of human cases of visceral leishmaniasis, yellow fever and malaria registered in Brazil in the period 2001-2016 were obtained from Ministry of Health's SINAN (BRASIL, 2020a) and the Epidemiological Surveillance Information System, SIVEP-Malaria (BRASIL, 2020c), by year and municipality of infection/residence.

For the application of climate suitability models, it is necessary that the input data be in the form of occurrence points, with geographical coordinates associated with each record (PETERSON, 2006; PETERSON et al., 2011). To this end, geographical coordinates of the centroids of the municipalities that presented at least 1 human case of each disease in the study period were used. Therefore, it is important to clarify that, in this type of analysis, the presence or absence of transmission is considered, not the incidence of diseases (i.e., number of cases per inhabitants).

However, among the three diseases studied, malaria has a strong spatial bias in its distribution within the country, since currently it occurs almost exclusively in the Amazon region (OLIVEIRA-FERREIRA et al., 2010). For this reason, only municipalities with high malaria incidence were selected for analysis (Figure 2). Municipal incidence was calculated by the empirical Bayesian estimation, which considers data-inherent spatial autocorrelation (CARVALHO; SOUZA-SANTOS, 2005). Then, only municipalities with incidence above the 90th percentile were selected and, among these, a subset of the centroids located at a minimum distance of $100 \mathrm{~km}$ (NAIMI et al., 2014) (Figure 2).
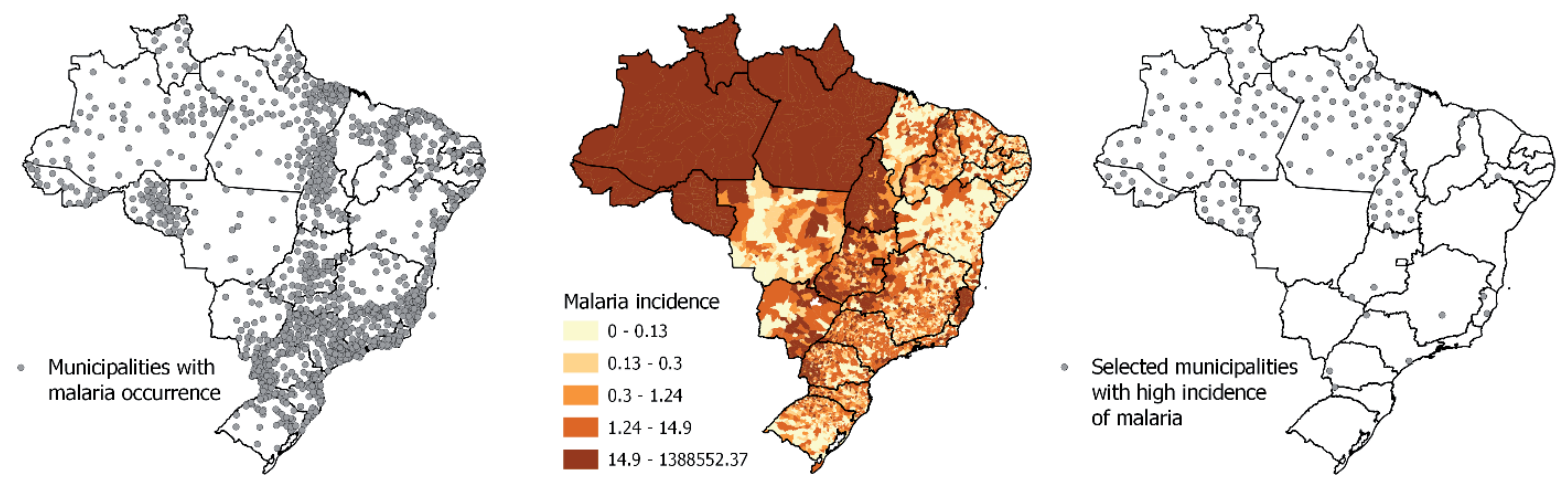

Figure 2 | Municipalities with occurrence of malaria in the baseline period (left), estimated incidence of malaria by municipality (center) and municipalities selected for models after consideration of incidence and geographical distance (right). 


\subsection{CLIMATE SUITABILITY MODELS}

For the construction of predictive models in global warming scenarios, the MaxEnt machine learning algorithm, based on the Maximum Entropy Model, was used (PHILLIPS; ANDERSON; SCHAPIRE, 2006). The model was originally proposed to predict species distributions based on environmental covariables for each cell in a grid (PHILLIPS; ANDERSON; SCHAPIRE, 2006). In this study, the climate variables were extracted for each point of presence of diseases (visceral leishmaniasis and yellow fever) or high incidence (malaria), and then compared with the distribution of the same variables extracted in 10,000 background points randomly distributed by the extension of the area of study. These represent the available environmental conditions for the occurrence of diseases and are essential definitions for the Maximum Entropy modeling process (ELITH et al., 2011; PHILLIPS; ANDERSON; SCHAPIRE, 2006).

The models were run using the dismo library (HIJMANS; PHILLIPS; ELITH, 2017) of software R (R CORE TEAM, 2017). All models were calibrated from $75 \%$ of the occurrence points reported during the study period. The remaining $25 \%$ were used to assess errors of omission in the models (percentage of non-predictable presence). The relative contribution of each variable were determined by the Jackknife test (ELITH et al., 2011). The models were assessed through the AUC index (area below the ROC curve, ALLOUCHE; TSOAR; KADMON, 2006), where values next to 1 indicate good models, 0.5 indicates models with random projections and below that, worse than a random model (ALLOUCHE; TSOAR; KADMON, 2006). After calibration and validation, models were then reprojected in warming scenarios of $1.5^{\circ} \mathrm{C}, 2^{\circ} \mathrm{C}$ and $4^{\circ} \mathrm{C}$.

\section{RESULTS}

Resulting maps represent climate suitability areas for disease occurrence. Colors were used to show the expected probability that climate conditions are suitable for the occurrence of diseases, with red indicating a high probability of suitable conditions for the occurrence of cases, yellow indicating conditions typical of those where the cases are found, and more greenish tones indicating low expected probability of adequate conditions. Difference maps among scenarios were also produced, from the spatial overlap between the future scenario and the baseline period. In those maps, colder colors represent areas that lose climate suitability in the future, and the warmer colors represent areas that gain climate suitability in the future.

\subsection{VISCERAL LEISHMANIASIS}

The climate suitability model for visceral leishmaniasis provided a good fit to the data (AUC $=0.816$ ) and low omission rate (16\%). Variables that contributed the most to this model were precipitation $(60.3 \%)$ and precipitation seasonality (13.1\%) (Figure 3).

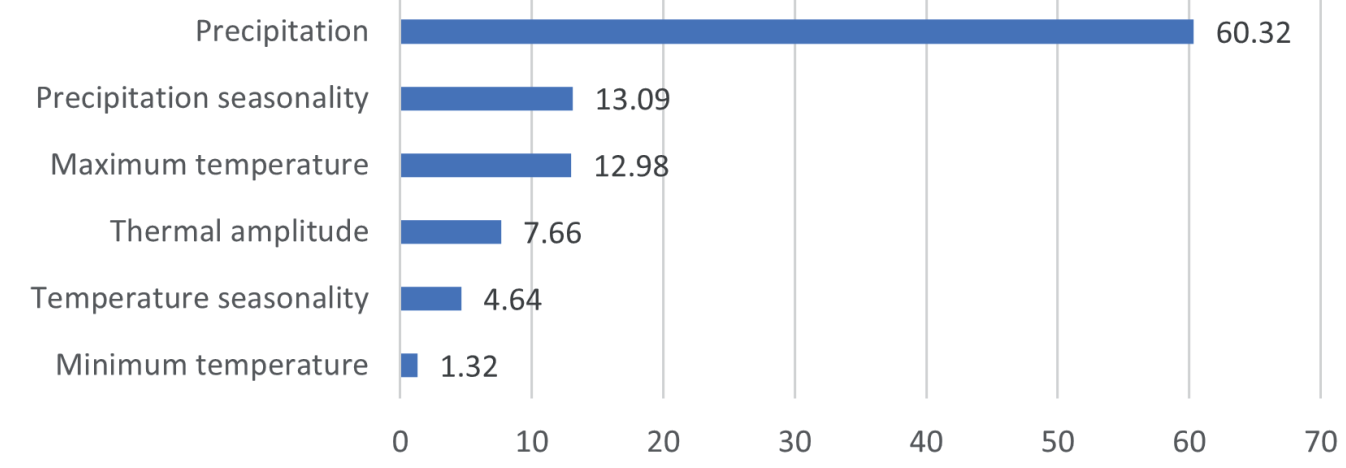

Figure 3 | Relative contribution of the climate variables for the gain of the climate suitability model for visceral leishmaniasis. 
Areas of high climate suitability for visceral leishmaniasis, according to the model, well represent the known distribution of the disease, which occurs mainly in the Northeastern, Center-West and Southeastern regions (Figure 4). This suitable area will be reduced according to warming scenarios, at different intensities depending on the scenario, with suitability loss in the Northern, Northeastern and Center-West regions, and some areas of increased suitability in the Southeastern and Southern regions, in addition to a strip on the northern coast of the states of Pará, Amapá and Maranhão (Figures 5-7).
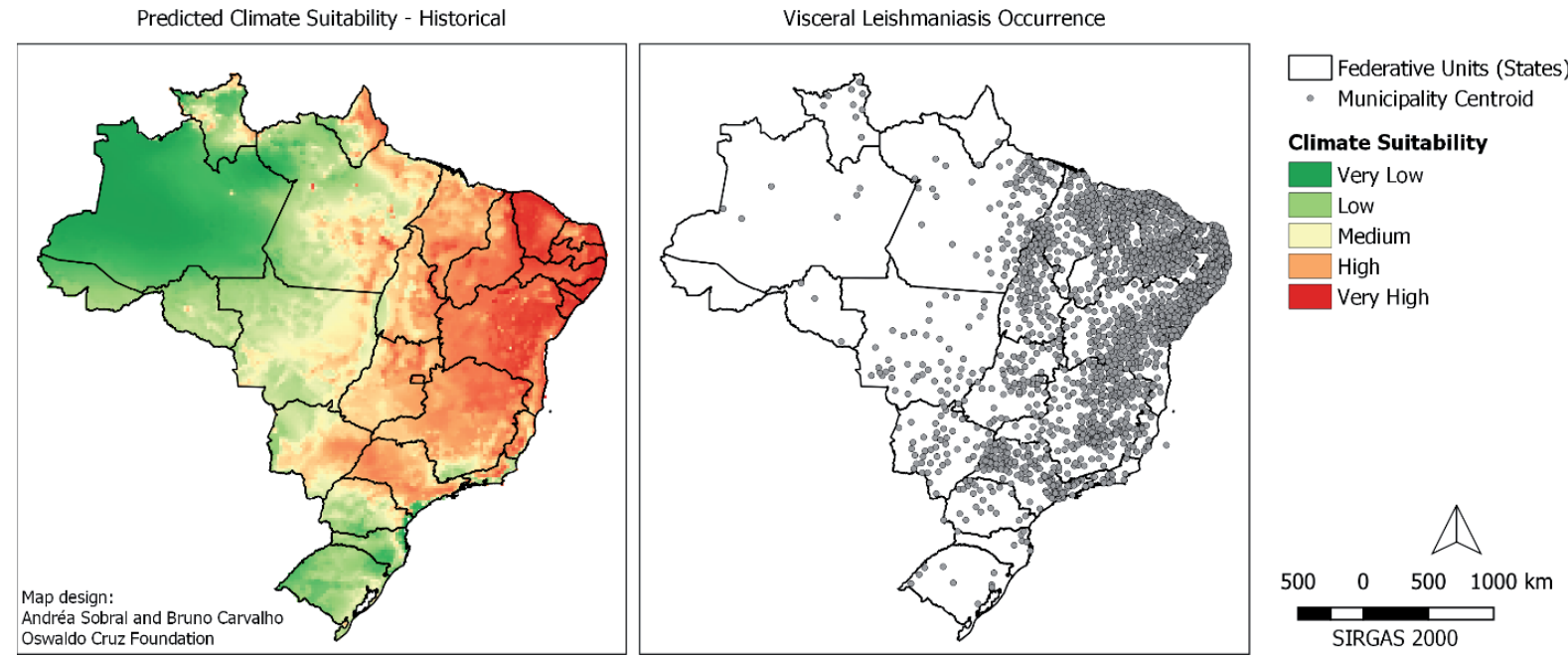

Figure 4 | Predicted climate suitability for visceral leishmaniasis and occurrence in Brazil. Left: historical baseline scenario Right: municipalities with disease occurrence.

\section{Source: Prepared by the authors.}

In the global warming scenario of $1.5^{\circ} \mathrm{C}$, the semi-arid region in the Northeast has presented decreased climate suitability for visceral leishmaniasis, while the Southeastern and Southern regions have increased climate suitability for the disease (Figure 5).

\section{Climate Suitability for Visceral Leishmaniasis $-1.5^{\circ} \mathrm{C}$ Global Warming Scenario}
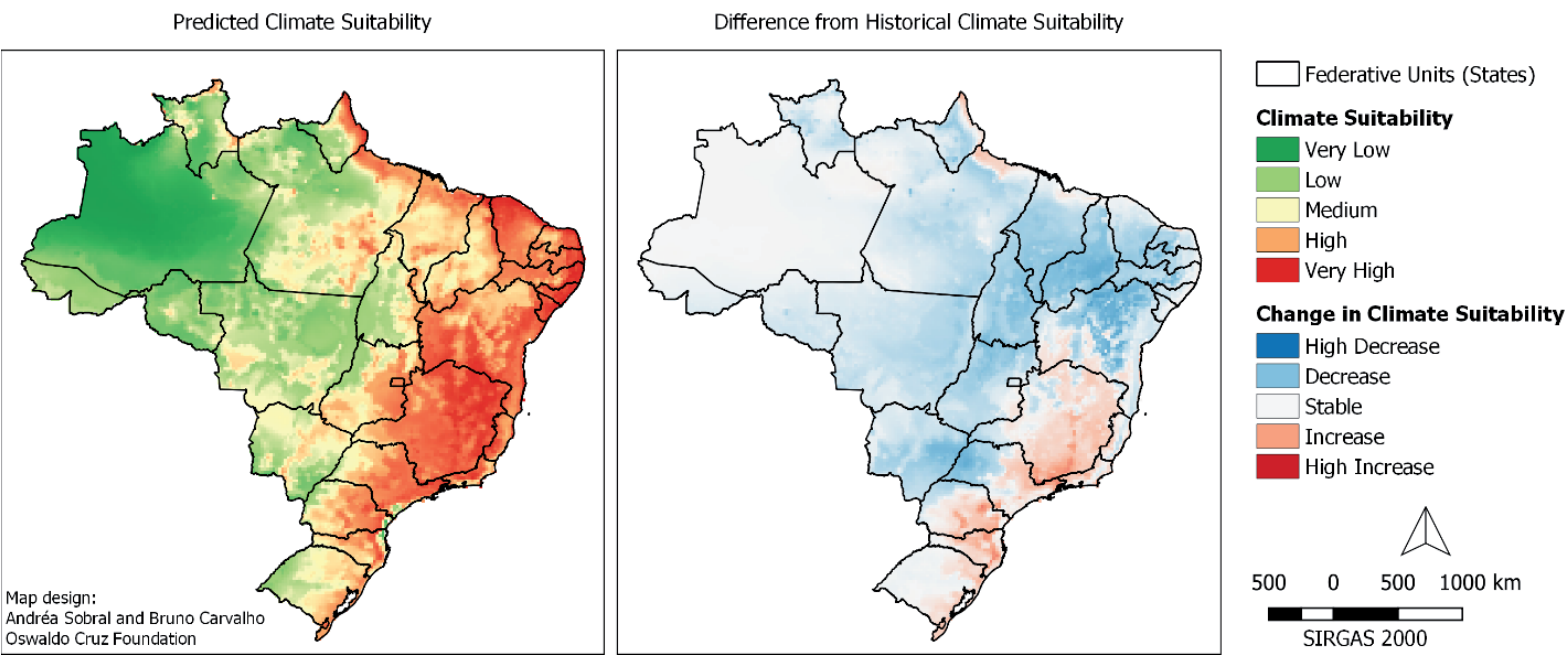

Figure 5 | Predicted climate suitability for visceral leishmaniasis in Brazil under the $1.5^{\circ} \mathrm{C}$ global warming scenario. Left: $1.5^{\circ} \mathrm{C}$ scenario. Right: difference when compared to the historical baseline scenario.

Source: prepared by the authors.

There is a downward trend of climate suitability for warming scenarios of $2^{\circ} \mathrm{C}$ and $4^{\circ} \mathrm{C}$. Especially in the warming scenario of $4^{\circ} \mathrm{C}$, decreased favorable climate conditions for the occurrence of the disease were observed in the Northeastern and Center-West regions, with an expansion of favorable climate 
condition areas in the Southeastern and Southern regions and a strip on the northern coast of the states of Pará, Amapá and Maranhão (Figures 6 and 7).

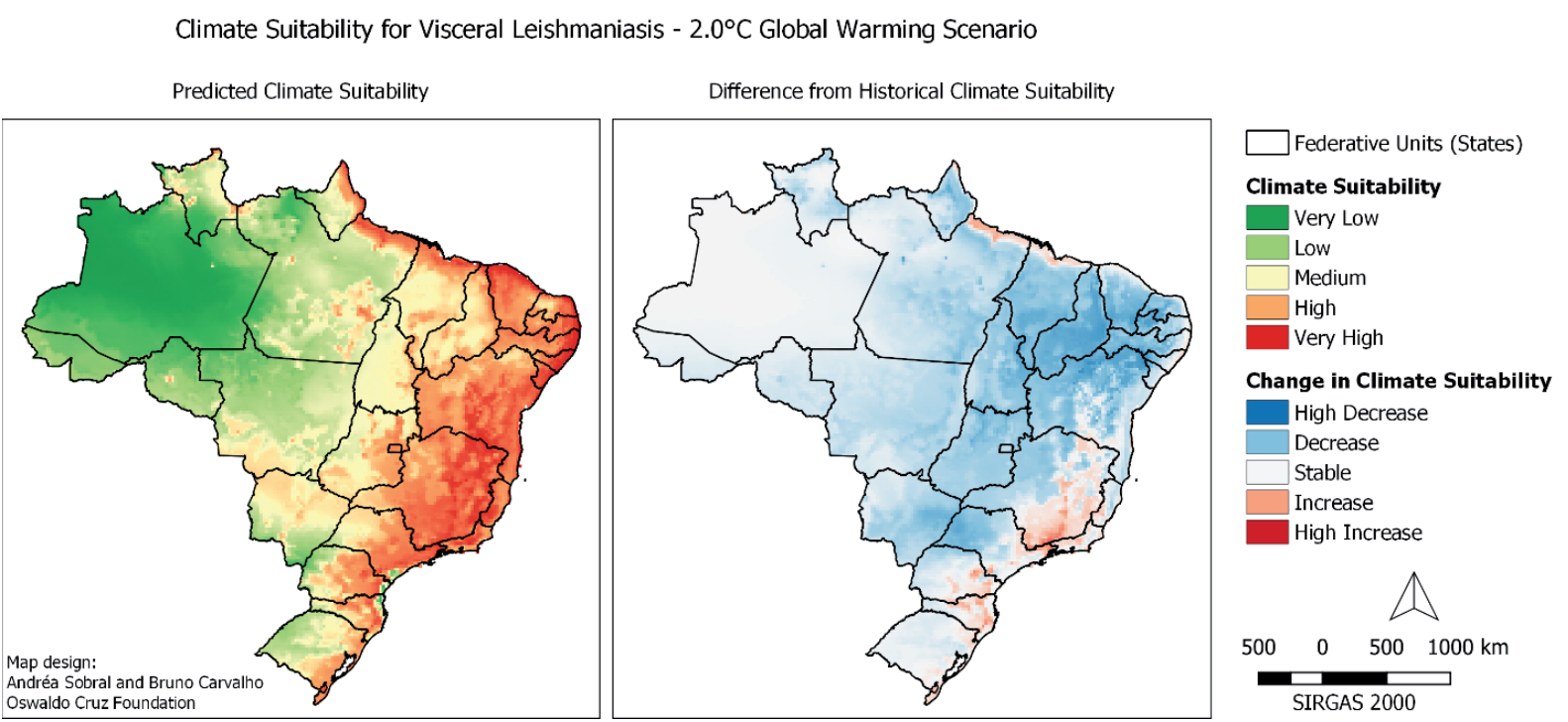

Figure 6 | Predicted climate suitability for visceral leishmaniasis in Brazil under the $2.0^{\circ} \mathrm{C} \mathrm{global} \mathrm{warming}$ scenario. Left: $2.0^{\circ} \mathrm{C}$ scenario. Right: difference when compared to the historical baseline scenario.

Source: Prepared by the authors.

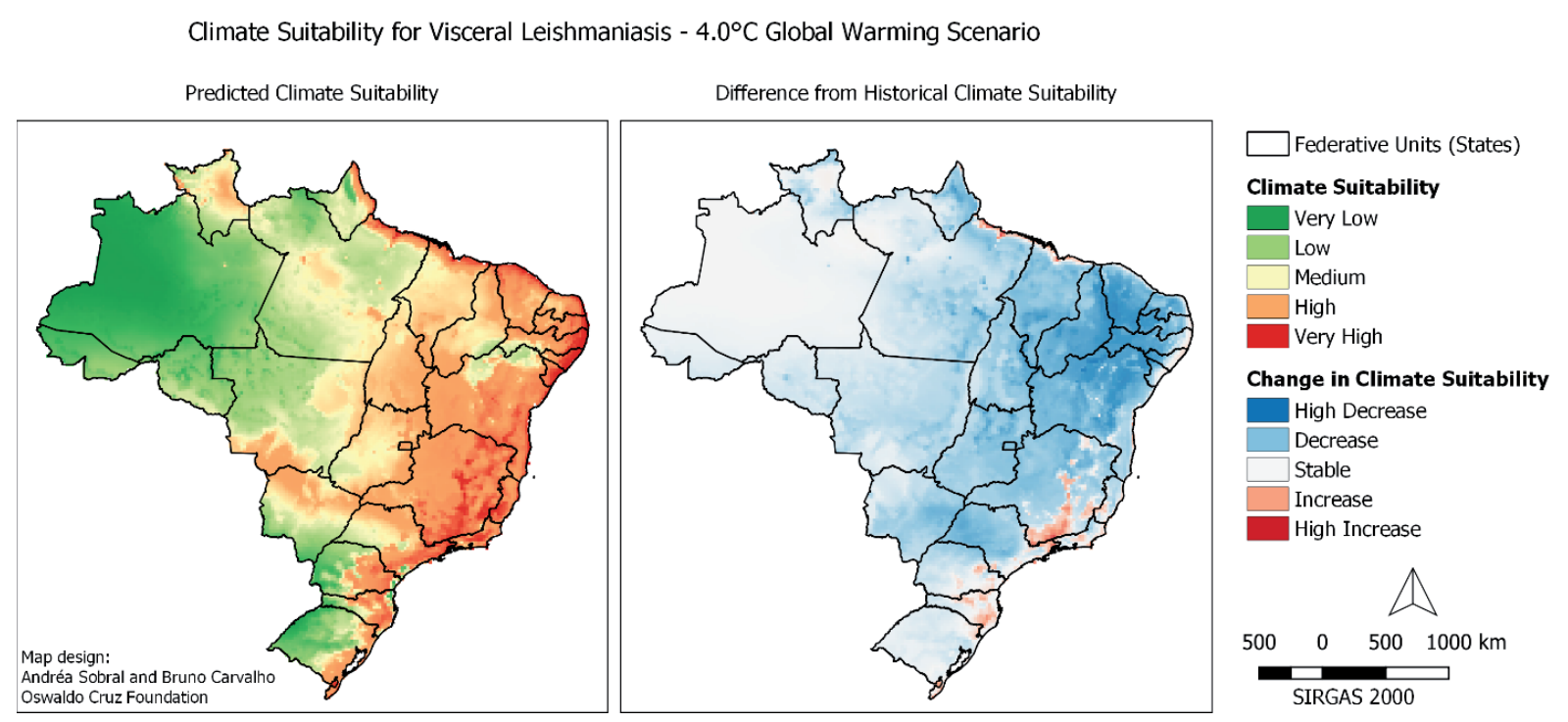

Figure 7 || Predicted climate suitability for visceral leishmaniasis in Brazil under the $4.0^{\circ} \mathrm{C}$ global warming scenario. Left: $4.0^{\circ} \mathrm{C}$ scenario. Right: difference when compared to the historical baseline scenario.

Source: Prepared by the authors.

\subsection{YELLOW FEVER}

The climate suitability model for yellow fever also provided a good fit to the data ( $A U C=0.865$ ) and low omission rate (19\%). Variables that contributed the most to this model were minimum temperature (51.7\%) and precipitation (19.7\%) (Figure 8). 


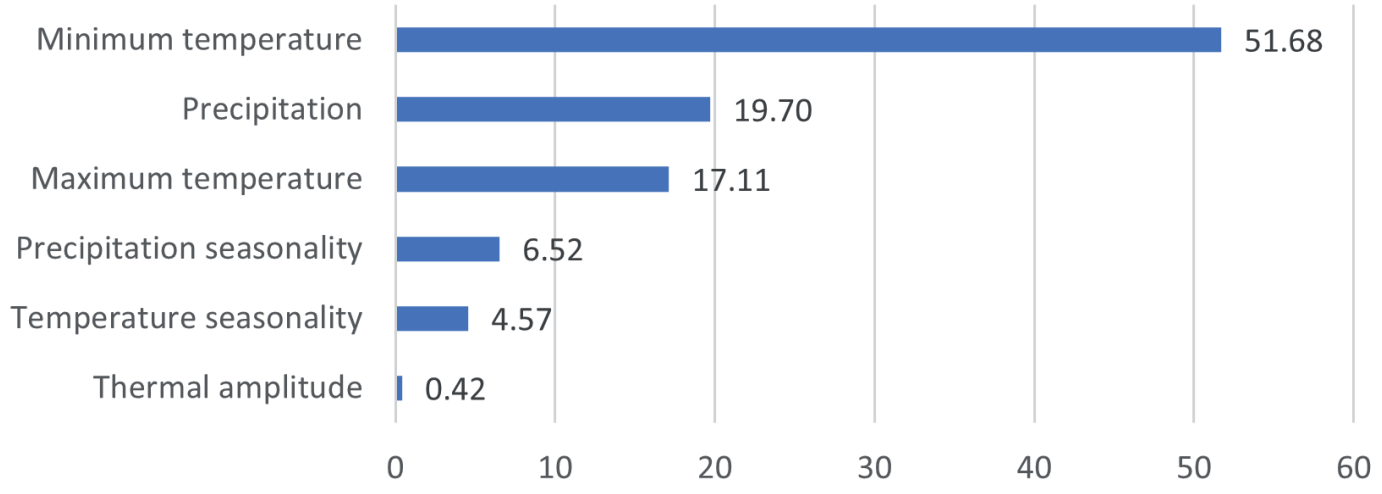

Figure 8 | Relative contribution of the climate variables for the gain of the climate suitability model for yellow fever.

Source: Prepared by the authors.

Areas of high climate suitability for yellow fever, according to the model, are distributed mainly in the Southeastern, Southern, Center-West and Northern regions (Figure 9). This suitable area will be significantly increased in warming scenarios, mainly in the Northern and Center-West regions (Figures 10-12).
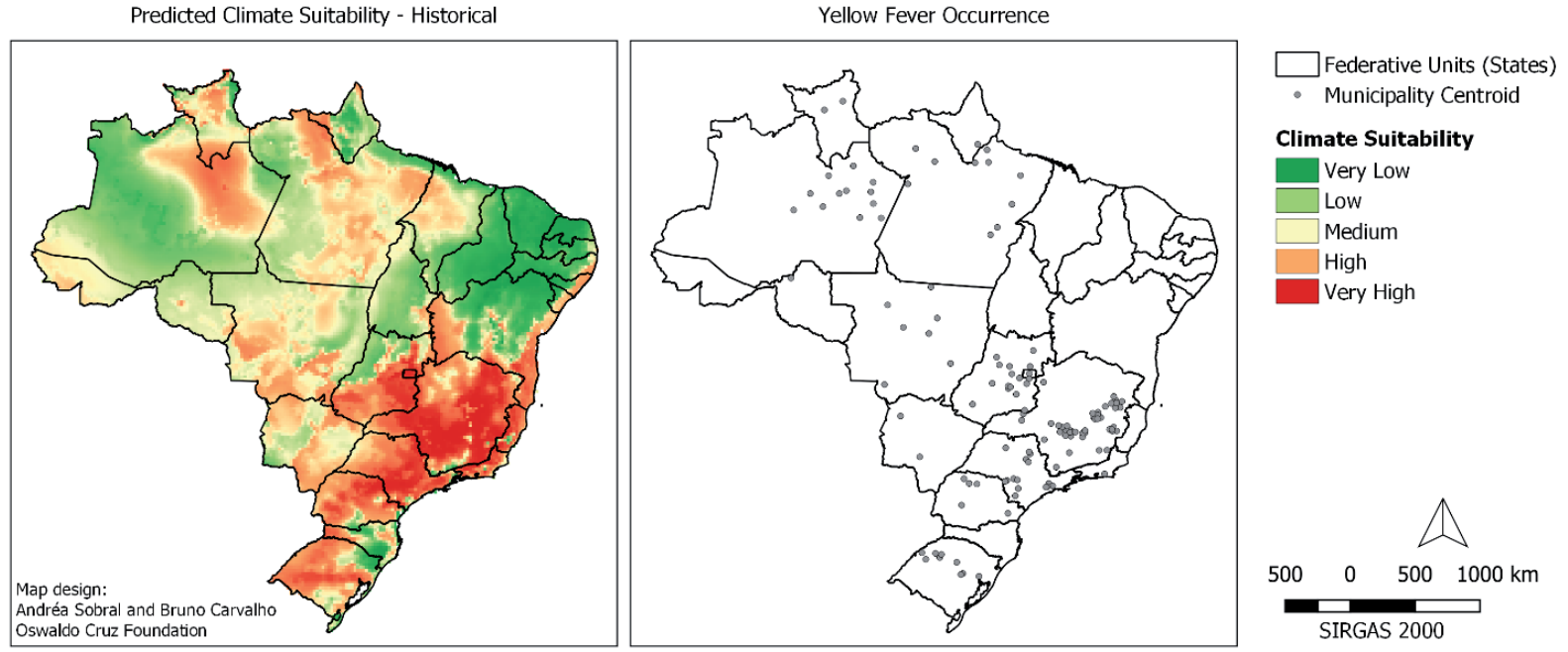

Figure 9 | Predicted climate suitability for yellow fever and occurrence in Brazil. Left: historical baseline scenario Right: municipalities with disease occurrence.

Source: Prepared by the authors.

In the global warming scenario of $1.5^{\circ} \mathrm{C}$, a decrease in the ideal climate conditions for Yellow Fever is observed in the Southeastern region, and an increase in these conditions is observed in the Center-West and Northern regions, mainly in the central regions of the states of Amazonas and Pará (Figure 10). 
Climate Suitability for Yellow Fever $-1.5^{\circ} \mathrm{C}$ Global Warming Scenario
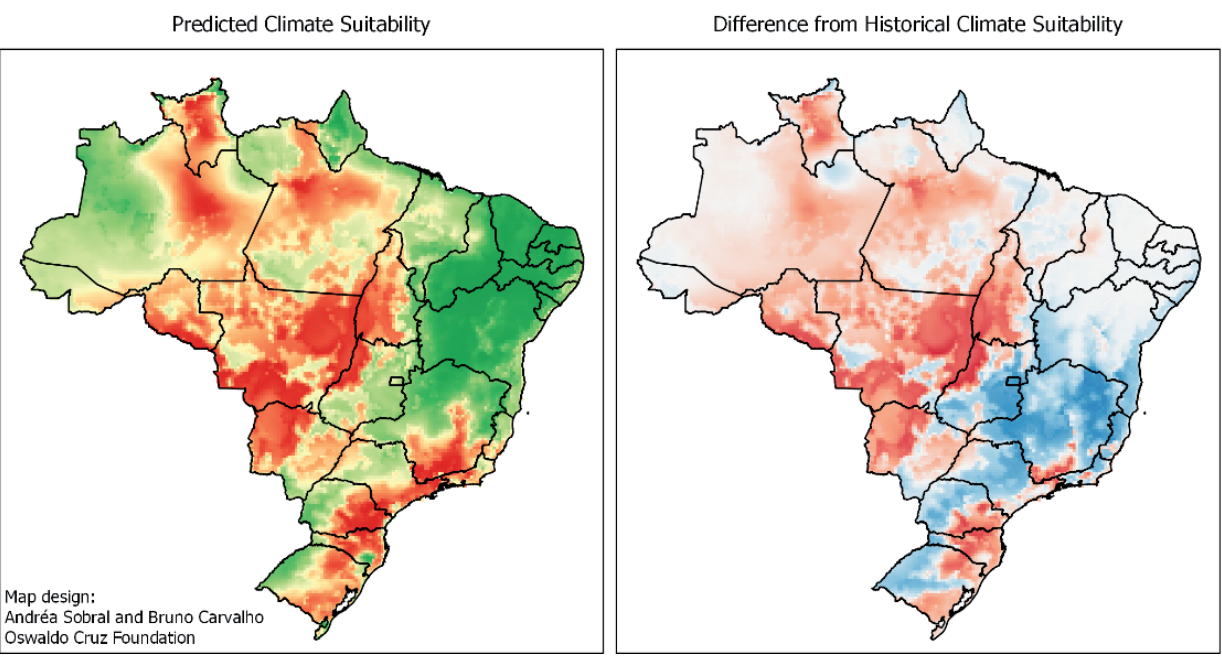

$\square$ Federative Units (States)

Climate Suitability

Very Low

Low

Medium

High

Very High

Change in Climate Suitability

High Decrease

Decrease

Stable

Increase

High Increase

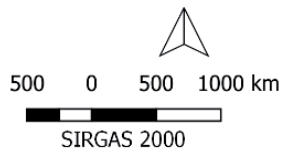

Figure 10 | Predicted climate suitability for yellow fever in Brazil under the $1.5^{\circ} \mathrm{C}$ global warming scenario. Left: $1.5^{\circ} \mathrm{C}$ scenario. Right: difference when compared to the historical baseline scenario.

Source: Prepared by the authors.

In the warming scenarios of $2^{\circ} \mathrm{C}$ and $4^{\circ} \mathrm{C}$, a change in the pattern of climate suitability general distribution for Yellow Fever is observed, which weakens in the Southeastern and Southern regions and now occupies the Amazon, including municipalities in the region of the so-called soybean arc, in the Center-West region (Figures 11 and 12).

Climate Suitability for Yellow Fever $-2.0^{\circ} \mathrm{C}$ Global Warming Scenario
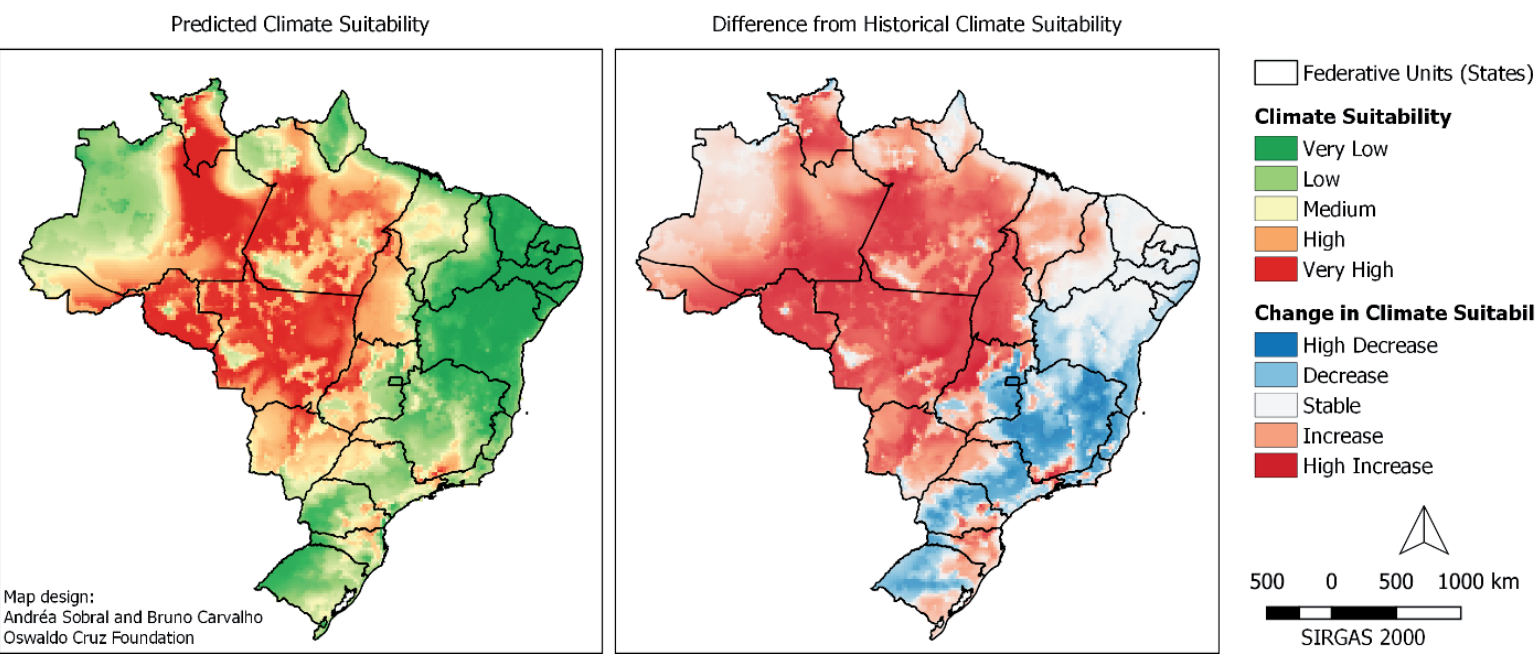

Change in Climate Suitability

High Decrease

Decrease

Stable

Increase

High Increase

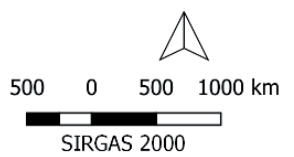

Figure 11 | Predicted climate suitability for yellow fever in Brazil under the $2.0^{\circ} \mathrm{C}$ global warming scenario. Left: $2.0^{\circ} \mathrm{C}$ scenario. Right: difference when compared to the historical baseline scenario.

Source: Prepared by the authors. 
Climate Suitability for Yellow Fever $-4.0^{\circ} \mathrm{C}$ Global Warming Scenario
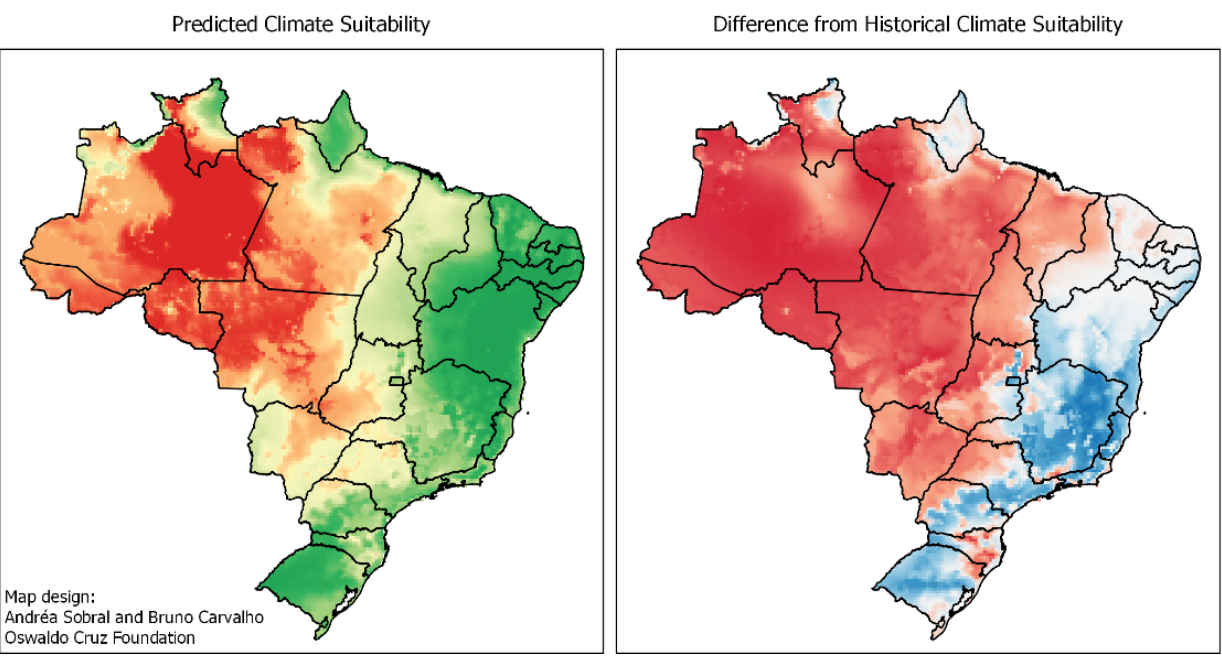

$\square$ Federative Units (States)

Climate Suitability

Very Low

Low

Medium

High

Very High

Change in Climate Suitability

High Decrease

Decrease

Stable

Increase

High Increase

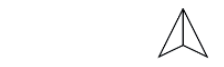

$500 \quad 0 \quad 500 \quad 1000 \mathrm{~km}$

SIRGAS 2000

Figure 12 | Predicted climate suitability for yellow fever in Brazil under the $4.0^{\circ} \mathrm{C}$ global warming scenario. Left: $4.0^{\circ} \mathrm{C}$ scenario. Right: difference when compared to the historical baseline scenario.

Source: Prepared by the authors.

\subsection{MALARIA}

The climate suitability model for malaria provided a good fit to the data $(A U C=0.704$ ) however lower than the visceral leishmaniasis and yellow fever models, with a very low omission rate (7.89\%). The minimum temperature variable contributed with over $50 \%$ for the model's response (Figure 13).

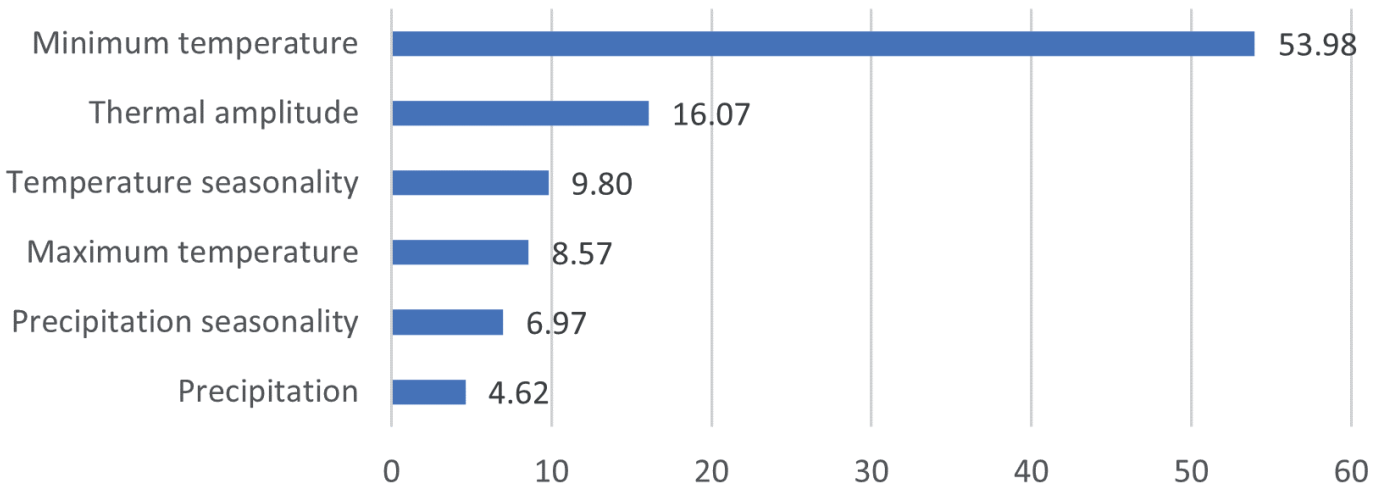

Figure 13 | Relative contribution of the climate variables for the gain of the climate suitability model for malaria.

Source: Prepared by the authors.

The model resulted in areas with high climate suitability for malaria mainly in the Northern region, in line with the incidence distribution presented previously (Figure 14). 

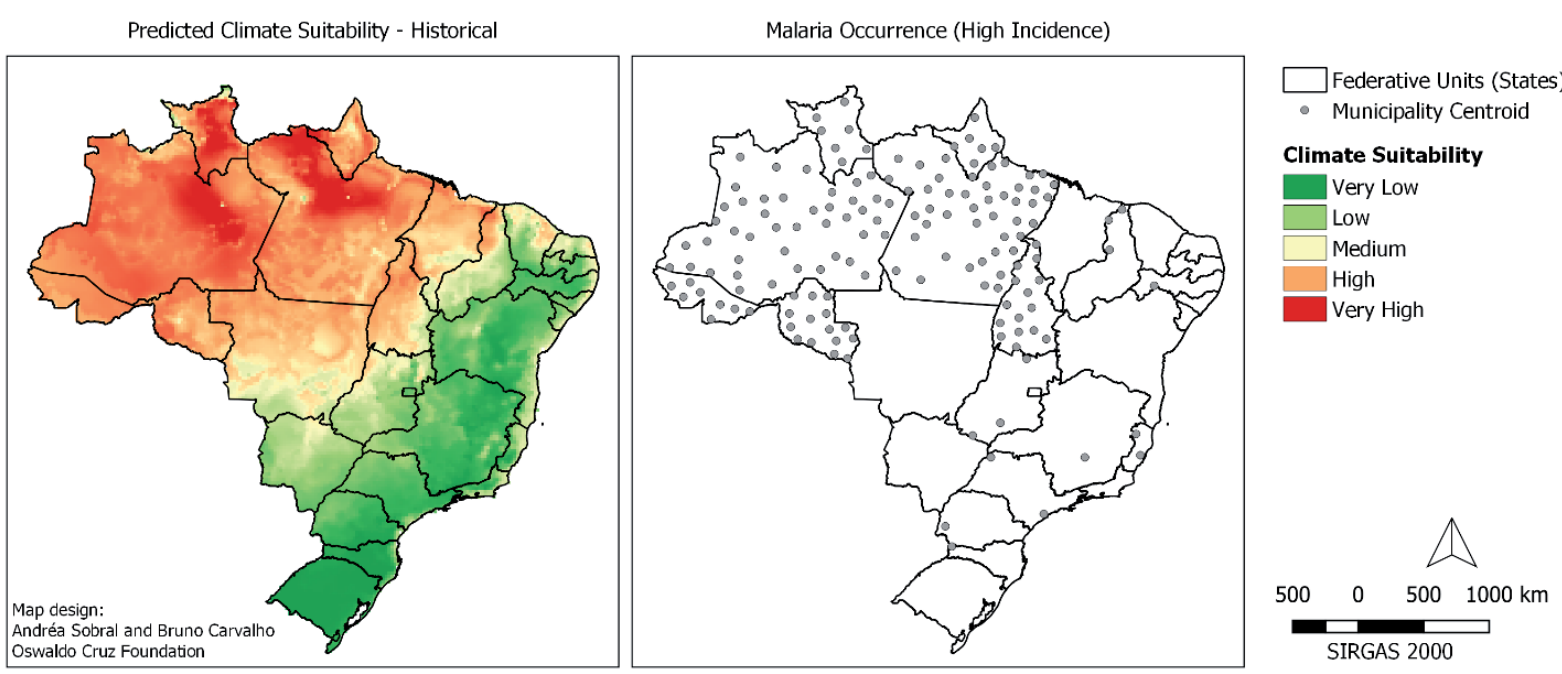

Figure 14 | Predicted climate suitability for malaria and high incidence municipalities in Brazil. Left: historical baseline scenario Right: municipalities selected for the analysis.

Source: Prepared by the authors.

Despite little difference in the regional distribution of malaria in the $1,5^{\circ} \mathrm{C}$ scenario, an increase is observed in climate suitability in the central-eastern region of the Amazon (Figure 15).

Climate Suitability for Malaria $-1.5^{\circ} \mathrm{C}$ Global Warming Scenario
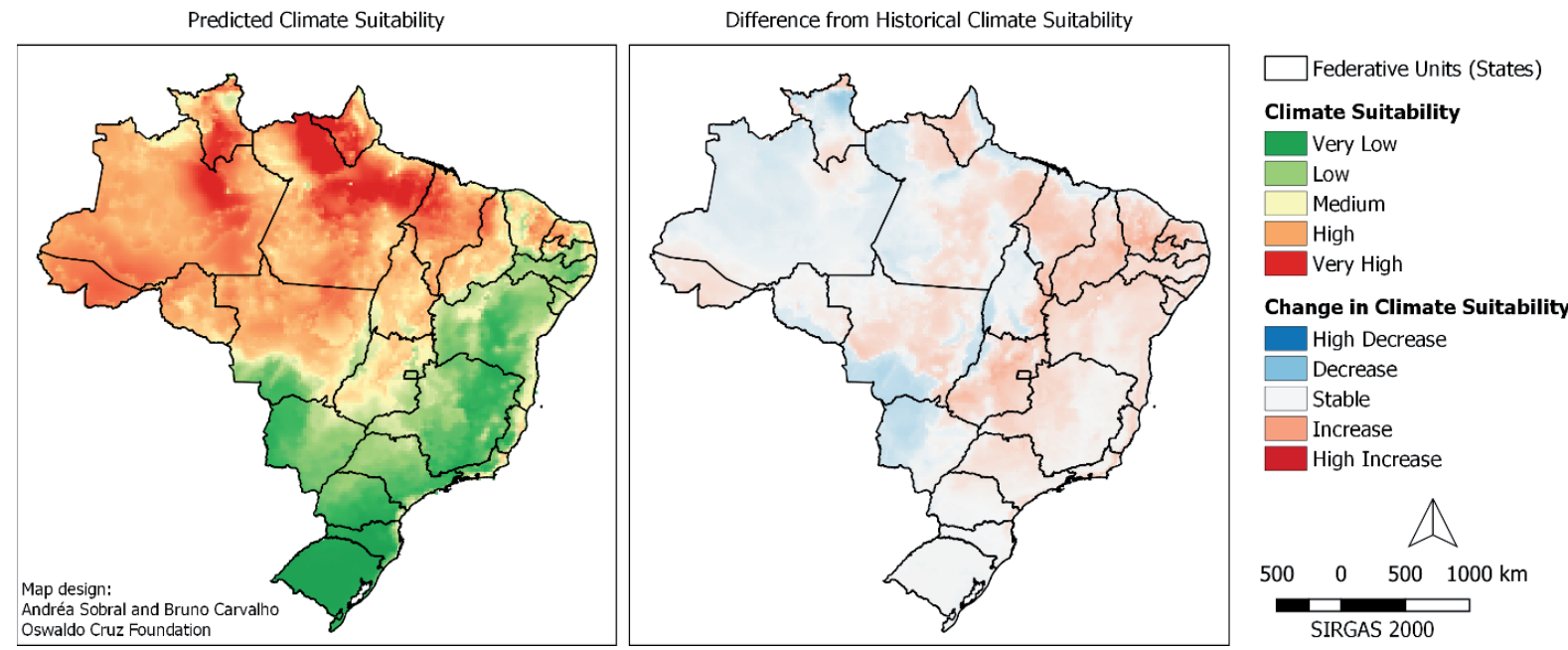

Figure 15 | Predicted climate suitability for malaria in Brazil under the $1.5^{\circ} \mathrm{C}$ global warming scenario. Left: $1.5^{\circ} \mathrm{C}$ scenario. Right: difference when compared to the historical baseline scenario.

Source: Prepared by the authors.

The warming scenario of $2^{\circ} \mathrm{C}$ reinforces increased favorable climate conditions in locations in northern Pará (Figure 16), while the $4^{\circ} \mathrm{C}$ scenario points to a concentration of greater climate suitability in western Amazon, the coast of the states of Pará and Maranhão, and part of the Northeastern region (Figure 17). 

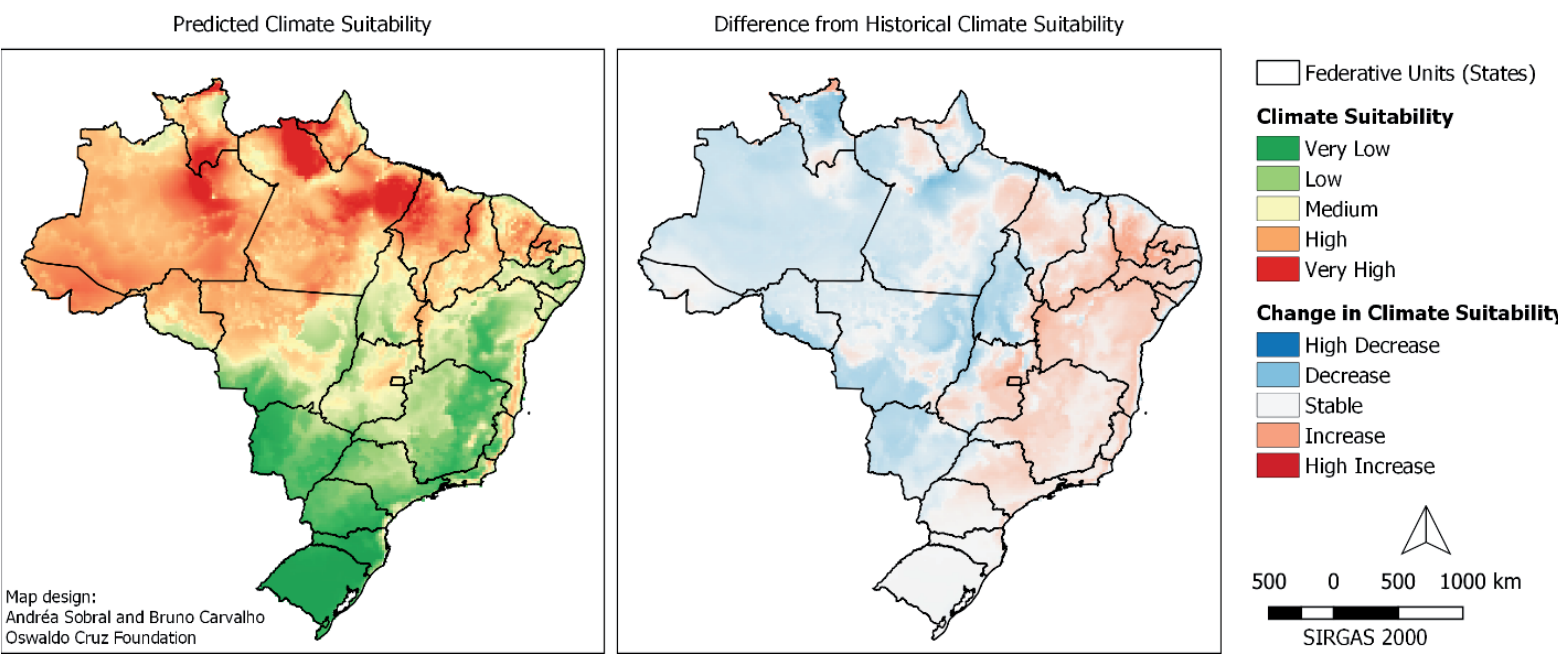

Figure 16 | Predicted climate suitability for malaria in Brazil under the $2.0^{\circ} \mathrm{C}$ global warming scenario. Left: $2.0^{\circ} \mathrm{C}$ scenario. Right: difference when compared to the historical baseline scenario.

Source: Prepared by the authors.

For the warming scenarios of $2^{\circ} \mathrm{C}$ (Figure 16) and $4^{\circ} \mathrm{C}$ (Figure 17) there is a gradual expansion of climate conditions that favor the occurrence of malaria to the Northeastern region, including the entire coast of the state of Bahia and, at $4^{\circ} \mathrm{C}$, they go as far as the north of the state of Minas Gerais (Figure 17).

Climate Suitability for Malaria $-4.0^{\circ} \mathrm{C}$ Global Warming Scenario
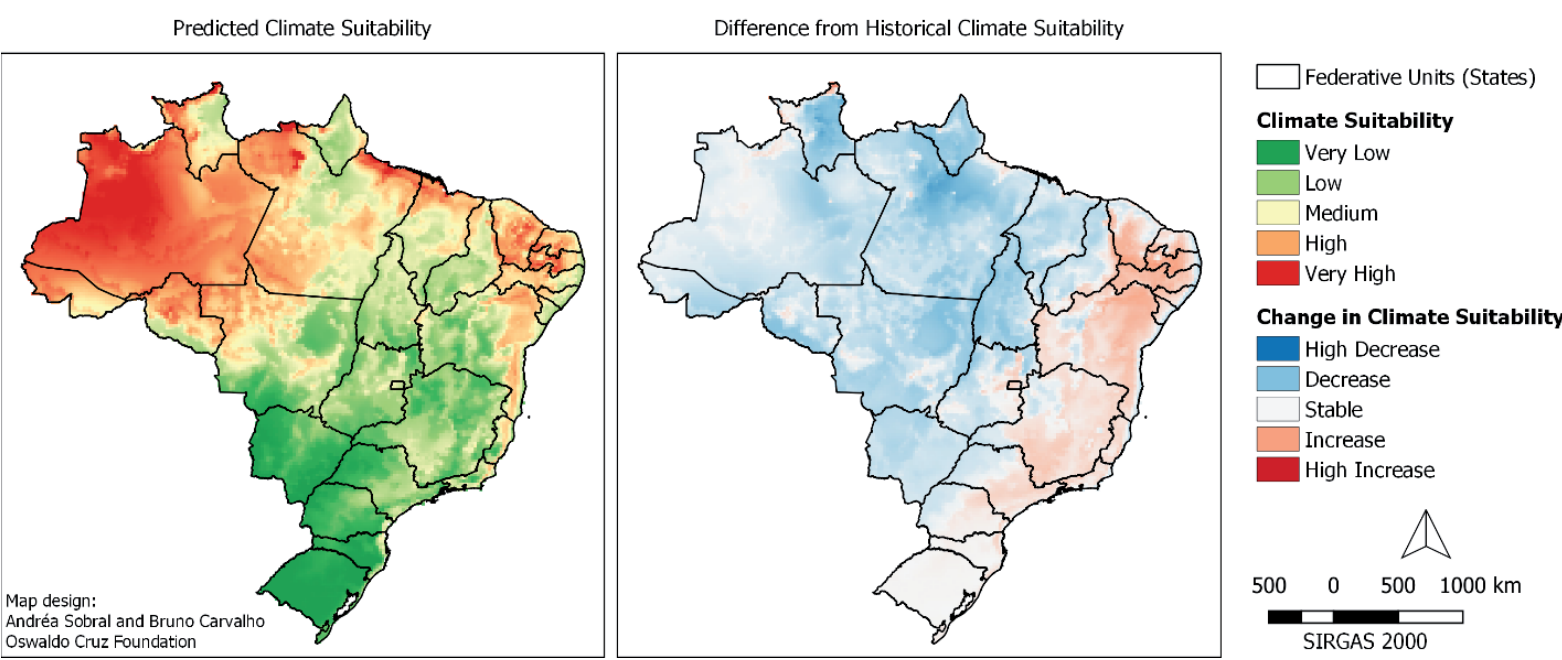

Figure 17 | Predicted climate suitability for malaria in Brazil under the $4.0^{\circ} \mathrm{C}$ global warming scenario. Left: $4.0^{\circ} \mathrm{C}$ scenario. Right: difference when compared to the historical baseline scenario.

Source: Prepared by the authors.

It is also important to emphasize the slight increase in climate suitability for malaria in the Northeastern, Southeastern and part of the Center-West (states of Goiás and Mato Grosso) regions in different scenarios, with a decrease in climate suitability in the state of Tocantins (Figures 15 to 17).

\section{DISCUSSION}

Brazil is a country with great social and cultural, ecological and climate complexity. Establishing climate thresholds for Brazil and its various regions, from which drastic and/or irreversible changes may arise in 
the occurrence of some diseases, especially vector-borne diseases, is a challenge for Brazilian science (BARCELLOS et al., 2009). For some vector species occurring in Brazil, these temperature thresholds have been determined in lab experiments (LAMBRECHTS et al., 2011; RIVAS et al., 2014). From the spatial point of view, few studies have assessed these species' geographic distribution in relation to climate variables, i.e., for species of mosquito vectors of malaria (LAPORTA et al., 2011, 2015), triatomine vectors of Chagas disease (GURGEL-GONÇALVES et al., 2012) and phlebotomine sand fly vectors of leishmaniasis (CARVALHO et al., 2015; DA COSTA; CORDEIRO; RANGEL, 2018).

However, most previously published studies do not include the use of scenarios produced by climate models to predict areas of potential distribution of vector-borne diseases in Brazil, as presented herein. Among the few existing ones, scenarios in the global extent of the distribution of malaria (CAMINADE et al., 2014) and dengue fever (MESSINA et al., 2019) may be indicated, in addition to a study on leishmaniasis in the Americas (MOO-LLANES, 2016).

In the present study, climate suitability maps were produced for three important vector-borne diseases in Brazil, in different scenarios of rising global temperature. The three diseases studied herein are largely influenced by climate and these scenarios describe possible climate condition paths for their occurrence in the future. Therefore, the outcomes presented herein identify areas in the country showing greater or lesser vulnerability to the occurrence of those diseases from the climate point of view only. Those places where climate will become more favorable to the occurrence of those diseases should be the target of Health Surveillance activities, as the density of existing vectors may increase, new populations of vectors may be dispersed to those areas, and pathogens may find a more favorable environment for their survival and consequent transmission.

However, climate change impacts on health will depend on the general health status of exposed populations, which, in turn, depend on future conditions of social health determinants (IPCC, 2014), and other important factors, such as universal health coverage, socio-environmental governance, public policies and the course of the country's development model (HACON et al., 2018)including the environmental impact assessment (EIA.

There are structural socio-environmental vulnerabilities for all analyzed diseases that were not included in the models, which considerably increase the risk of vector diseases occurrence, and exposure modifying factors (BARCELLOS et al., 2009), i.e., deforestation, fires, agribusiness, mining, timber extraction or artisanal gold mining activities in the Brazilian Amazon, which directly impact the Amazon biome and its ecosystem services(LAPOLA et al., 2014, 2018; LOVEJOY; NOBRE, 2018), also resulting in impacts on human health and quality of life of affected populations, which are characterized as the most vulnerable and the poorest in the country (BARROS; GONÇALVES; HACON, 2014; MENDES et al., 2016; RUFINO et al., 2016).

Visceral leishmaniasis has two transmission patterns (BRASIL, 2014). The first is related to rural areas, the outskirts of large cities and areas with high concentration of socioeconomically vulnerable populations. The second is more recent, and reflects the disease's urbanization process, occurring in medium and large cities, mainly in the Southeastern and Center-West regions of the country (RANGEL et al., 2018; SALOMÓN et al., 2015). In the global warming scenario of $1.5^{\circ} \mathrm{C}$, the semi-arid region in the Northeast has presented decreased climate suitability for visceral leishmaniasis, while the Southeastern and Southern regions have increased climate suitability for the disease (Figure 5). These regions are currently occupied by the Lutzomyia longipalpis vector, and in a study about its distribution in the Americas in climate change scenarios, areas of probable expansion were identified, mainly in the states of Minas Gerais and Rio de Janeiro (PETERSON et al., 2017).

The combination, in those regions, of favorable climate for transmission (as shown in the outcomes described herein), local populations of the vector that are highly adapted to the peridomestic environment (RANGEL et al., 2018) and poor housing conditions on the outskirts of cities and rural 
areas (SALOMÓN et al., 2015) may result in an increased risk of transmission of visceral leishmaniasis, if climate mitigation measures are not adopted in the country and we move to the scenario of greater global warming.

In relation to yellow fever, it is important to highlight its recent reemergence, with the spread of the virus to areas with no record of circulation of the disease for decades (BRASIL, 2020b; POSSAS et al., 2018). The significant increase in epidemics in 2017/2018 preceded local outbreaks of virus transmission and led to reinforcements in local vaccination campaigns outside the area traditionally considered endemic (FERNANDES et al., 2017; POSSAS et al., 2018).

The results presented herein, considering the $1,5^{\circ} \mathrm{C}$ warming scenario (which is the closest to our current reality), corroborate the occurrence of these recent outbreaks in the Southeastern and Southern regions. In other scenarios, where global warming reaches higher temperatures, increased climate suitability in the Amazon is a concern, as it is known to be an endemic region for the transmission of sylvatic yellow fever, with the numbers of cases declining in the past few decades after extensive vaccination, but rising again in 2017 (MINISTÉRIO DA SAÚDE, 2019). There, traditional peoples and communities are at risk, and in addition to socioeconomic vulnerabilities, they are in greater contact with wild vector populations, who can benefit from more favorable climate conditions and thus aggravate the transmission of the disease in the region.

For malaria, the interpretation of the results is slightly different from the previous ones, as they represent favorable climate conditions to the high incidence of the disease. This means that, although malaria in Brazil occurs almost exclusively in the Amazon region (OLIVEIRA-FERREIRA et al., 2010), in areas of the country where sporadic cases of extra-Amazonian malaria already occur (mainly in the Atlantic Forest), their incidence may be increased due to better climate conditions for transmission. These outcomes corroborate recent studies showing that mosquitoes in the Kerteszia group in the Atlantic Forest present increased survival rates in higher temperatures, in addition to reducing the extrinsic incubation period of Plasmodium falciparum and $P$. vivax, increasing local transmission (DE AZEVEDO et al., 2020).

\section{FINAL CONSIDERATIONS}

This study made it possible to produce relevant information to show spatial distribution trends of vectorborne diseases in climate conditions within the RCP8.5 scenario, i.e., maintaining the current rate of GHG emissions (VAN VUUREN et al., 2011). It is important to emphasize that projections of scenarios and climate situations that the planet may reach are the result of the current world's development options. Therefore, in the coming years or decades, the world may follow different directions in terms of development options and, consequently, GHG emissions scenarios. In the face of a range of possible futures for the health sector, these scenarios have been used not to predict the future, but rather to better understand uncertainties associated with future climate change (MOSS et al., 2010). Given that the occurrence of infectious diseases is a complex and multi-factorial process, the results presented herein indicate only one of the possible consequences, within the Brazilian territory, of not adopting measures to mitigate climate change.

\section{ACKNOWLEDGEMENTS}

Authors thank the support received from CNPq/FINEP, Health and Climate sub-network (CNPq: No. 550022/2014-7; FINEP: № 01.13.0353.00; CNPq processes No. 312932/2017-20, 381160/2018$1,381446 / 2019-0)$ and the Public Health and Environment Program of the Sergio Arouca National School of Public Health/FIOCRUZ. This article was written in the context of the postdoctoral fellowship by Bruno Moreira de Carvalho at the Interdisciplinary Laboratory for Entomological Surveillance in 
Diptera and Hemiptera/FIOCRUZ (CAPES Program of National Institutes of Science and Technology INCT 88887.136402/2017-00).

\section{REFERENCES}

ALKISHE, A. et al. Recognizing sources of uncertainty in disease vector ecological niche models: an example with the tick Rhipicephalus sanguineus sensu lato. Perspectives in Ecology and Conservation, v. 18, n. 2, p. 91-102, 1 abr. 2020.

ALLOUCHE, O.; TSOAR, A.; KADMON, R. Assessing the accuracy of species distribution models: prevalence, kappa and the true skill statistic (TSS). Journal of Applied Ecology, v. 43, n. 6, p. 1223-1232, 2006.

ALMEIDA, M. A. B. DE. et al. Predicting Yellow Fever Through Species Distribution Modeling of Virus, Vector, and Monkeys. EcoHealth, v. 16, n. 1, p. 95-108, 1 mar. 2019.

ALTO, B. W.; JULIANO, S. A. Precipitation and Temperature Effects on Populations of Aedes albopictus (Diptera: Culicidae): implications for range expansion. Journal of Medical Entomology, v. 38, n. 5, p. 646-656, 1 set. 2001.

ALVAR, J. et al. Leishmaniasis Worldwide and Global Estimates of Its Incidence. PLOS ONE, v. 7, n. 5, p. e35671, 31 maio 2012.

ARBOlEDA, S.; JARAMILLO-O., N.; PETERSON, A. T. Mapping Environmental Dimensions of Dengue Fever Transmission Risk in the Aburrá Valley, Colombia. International Journal of Environmental Research and Public Health, v. 6, n. 12, p. 3040-3055, dez. 2009.

ARTUN, O. Ecological niche modeling for the prediction of cutaneous leishmaniasis epidemiology in current and projected future in Adana, Turkey. Journal of Vector Borne Diseases, v. 56, n. 2, p. 127, 4 jan. 2019.

AZEVEDO, T. S. DE. et al. Kerteszia cruzii and extra-Amazonian malaria in Brazil: Challenges due to climate change in the Atlantic Forest. Infection, Genetics and Evolution, v. 85, p. 104456, 1 nov. 2020.

BABAIE, J. et al. A systematic evidence review of the effect of climate change on malaria in Iran. Journal of Parasitic Diseases, v. 42, n. 3, p. 331-340, 1 set. 2018.

BARCELLOS, C. et al. Mudanças climáticas e ambientais e as doenças infecciosas: cenários e incertezas para o Brasil. Epidemiologia e Serviços de Saúde, v. 18, n. 3, p. 285-304, set. 2009.

BARROS, M. M. A.; GONÇALVES, K. DOS S.; HACON, S. DE S. Reinternações hospitalares por doenças respiratórias em menores de 12 anos e as queimadas em Porto Velho - RO, na Amazônia Ocidental. InterfacEHS - Revista de Saúde, Meio Ambiente e Sustentabilidade, v. 8, n. 3, 2014.

BENEDICT, M. Q. et al. Spread of the Tiger: global risk of invasion by the mosquito Aedes albopictus. Vector-Borne and Zoonotic Diseases, v. 7, n. 1, p. 76-85, 1 mar. 2007.

BENNETT, H. et al. Health and equity impacts of climate change in Aotearoa - New Zealand, and health gains from climate action. New Zealand Medical Journal, v. 127, n. 1406, p. 16, 2014.

BESERRA, E. B. et al. Efeitos da temperatura no ciclo de vida, exigências térmicas e estimativas do número de gerações anuais de Aedes aegypti (Diptera, Culicidae). Iheringia. Série Zoologia, v. 99, n. 2, p. 142-148, jun. 2009.

BRASIL. Manual de Vigilância e Controle da Leishmaniose Visceral. Brasília, DF: Editora MS, 2014.

BRASIL. Sistema de Informação de Agravos de Notificação - Sinan. Epidemiológicas e Morbidade - Datasus. Disponível em: <http://datasus1.saude.gov.br/informacoes-de-saude/tabnet/epidemiologicas-e-morbidade>. Acesso em: 10 jan. 2020.

BRASIL. Boletim epidemiológico da Febre Amarela no Brasil 2019/2020. Rede Internacional de Educação de Técnicos em Saúde - Rets. Disponível em: <http://www.rets.epsjv.fiocruz.br/biblioteca/boletim-epidemiologicoda-febre-amarela-no-brasil-20192020>. Acesso em: 6 set. 2020. 
BRASIL. Malária, Sistema de Informação de Vigilância Epidemiológica - Sivep. Disponível em: <http:// portalweb04.saude.gov.br/sivep_malaria/>. Acesso em: 10 jan. 2020.

BRASIL. Ministério da Saúde. Vigilância em saúde no Brasil 2003|2019: da criação da Secretaria de Vigilância em Saúde aos dias atuais. Boletim Epidemiológico. Disponível em: <http://www.saude.gov.br/ boletinsepidemiologicos>. Acesso em: 10 nov. 2020.

CAMINADE, C. et al. Impact of climate change on global malaria distribution. Proceedings of the National Academy of Sciences, v. 111, n. 9, p. 3286-3291, 4 mar. 2014.

CAMPOS, G. S.; BANDEIRA, A. C.; SARDI, S. I. Zika Virus Outbreak, Bahia, Brazil. Emerging Infectious Diseases, v. 21, n. 10, p. 1885-1886, out. 2015.

CARDOSO-LEITE, R. et al. Recent and future environmental suitability to dengue fever in Brazil using species distribution model. Transactions of The Royal Society of Tropical Medicine and Hygiene, v. 108, n. 2, p. 99-104, 1 fev. 2014.

CARVALHO, B. M. et al. Ecological Niche Modelling Predicts Southward Expansion of Lutzomyia (Nyssomyia) flaviscutellata (Diptera: Psychodidae: Phlebotominae), Vector of Leishmania (Leishmania) amazonensis in South America, under Climate Change. PLOS ONE, v. 10, n. 11, p. e0143282, 30 nov. 2015.

CARVALHO, B. M.; RANGEL, E. F.; VALE, M. M. Evaluation of the impacts of climate change on disease vectors through ecological niche modelling. Bulletin of Entomological Research, v. 107, n. 4, p. 419-430, ago. 2017.

CARVALHO, M. S.; SOUZA-SANTOS, R. Análise de dados espaciais em saúde pública: métodos, problemas e perspectivas. Cadernos de Saúde Pública, v. 21, p. 361-378, abr. 2005.

CASTRO, M. C.; WILSON, M. E.; BLOOM, D. E. Disease and economic burdens of dengue. The Lancet Infectious Diseases, v. 17, n. 3, p. e70-e78, 1 mar. 2017.

CELLA, W. et al. Do climate changes alter the distribution and transmission of malaria? Evidence assessment and recommendations for future studies. Revista da Sociedade Brasileira de Medicina Tropical, v. 52, p. e20190308, 2019.

CHOU, S. C. et al. Evaluation of the Eta Simulations Nested in Three Global Climate Models. American Journal of Climate Change, v. 03, n. 05, p. 438, 25 dez. 2014.

COSTA, S. M. DA; CORDEIRO, J. L. P.; RANGEL, E. F. Environmental suitability for Lutzomyia (Nyssomyia) whitmani (Diptera: Psychodidae: Phlebotominae) and the occurrence of American cutaneous leishmaniasis in Brazil. Parasites \& Vectors, v. 11, n. 1, p. 155, 7 mar. 2018.

ELITH, J. et al. A statistical explanation of MaxEnt for ecologists. Diversity and Distributions, v. 17, n. 1, p. 43-57, 2011.

FERNANDES, N. C. C. DE A. et al. Outbreak of Yellow Fever among Nonhuman Primates, Espírito Santo, Brazil, 2017. Emerging Infectious Diseases, v. 23, n. 12, p. 2038-2041, dez. 2017.

FICK, S. E.; HIJMANS, R. J. WorldClim 2: new 1-km spatial resolution climate surfaces for global land areas. International Journal of Climatology, v. 37, n. 12, p. 4302-4315, 2017.

FOURNET, F. et al. Effective surveillance systems for vector-borne diseases in urban settings and translation of the data into action: a scoping review. Infectious Diseases of Poverty, v. 7, n. 1, p. 99, 3 set. 2018.

GASPARRINI, A. et al. Mortality risk attributable to high and low ambient temperature: a multicountry observational study. The Lancet, v. 386, n. 9.991, p. 369-375, 25 jul. 2015.

GRACIE, R. et al. Geographical Scale Effects on the Analysis of Leptospirosis Determinants. International Journal of Environmental Research and Public Health, v. 11, n. 10, p. 10366-10383, out. 2014.

GUISAN, A.; ZIMMERMANN, N. E. Predictive habitat distribution models in ecology. Ecological Modelling, v. 135, n. 2, p. 147-186, 5 dez. 2000. 
GURGEL-GONÇALVES, R. et al. Geographic Distribution of Chagas Disease Vectors in Brazil Based on Ecological Niche Modeling. Research Article. Disponível em: <https://www.hindawi.com/journals/jtm/2012/705326/>. Acesso em: 11 nov. 2020.

HACON, S. DE S. et al. Challenges and Prospects for Integrating the Assessment of Health Impacts in the Licensing Process of Large Capital Project in Brazil. International Journal of Health Policy and Management, v. 7, n. 10, p. $885-888,30$ jun. 2018.

HIJMANS, R. J. et al. Dismo Species Distribution Modeling. [s.l: s.n.]. 2015.

HLAVACOVA, J.; VOTYPKA, J.; VOLF, P. The Effect of Temperature on Leishmania (Kinetoplastida: Trypanosomatidae) Development in Sand Flies. Journal of Medical Entomology, v. 50, n. 5, p. 955-958, 1 set. 2013.

HORTA, M. A. et al. Temporal relationship between environmental factors and the occurrence of dengue fever. International Journal of Environmental Health Research, v. 24, n. 5, p. 471-481, 3 set. 2014.

IPCC (ED.). Climate change 2014: mitigation of climate change. Working Group III contribution to the Fifth Assessment Report of the Intergovernmental Panel on Climate Change. New York, NY: Cambridge University Press, 2014

IPCC. Summary for Policymakers: Global Warming of 1.5 C. Geneva: IPCC, 2018.

KINGSLEY, S. L. et al. Current and Projected Heat-Related Morbidity and Mortality in Rhode Island. Environmental Health Perspectives, v. 124, n. 4, p. 460-467, 1 abr. 2016.

KOVATS, R. S. et al. Early effects of climate change: do they include changes in vector-borne disease? Philosophical Transactions of the Royal Society of London. Series B: Biological Sciences, v. 356, n. 1.411, p. 1057-1068, 29 jul. 2001.

LAMBRECHTS, L. et al. Impact of daily temperature fluctuations on dengue virus transmission by Aedes aegypti. Proceedings of the National Academy of Sciences, v. 108, n. 18, p. 7460-7465, 3 maio 2011.

LAPOLA, D. M. et al. Pervasive transition of the Brazilian land-use system. Nature Climate Change, v. 4, n. 1, p. 27-35, jan. 2014.

LAPOLA, D. M. et al. Limiting the high impacts of Amazon forest dieback with no-regrets science and policy action. Proceedings of the National Academy of Sciences, v. 115, n. 46, p. 11671-11679, 13 nov. 2018.

LAPORTA, G. Z. et al. Habitat suitability of Anopheles vector species and association with human malaria in the Atlantic Forest in south-eastern Brazil. Memórias do Instituto Oswaldo Cruz, v. 106, p. 239-245, ago. 2011.

LAPORTA, G. Z. et al. Malaria vectors in South America: current and future scenarios. Parasites \& Vectors, v. 8, n. 1, p. 426, 19 ago. 2015.

LIPPI, C. A. et al. Geographic shifts in Aedes aegypti habitat suitability in Ecuador using larval surveillance data and ecological niche modeling: implications of climate change for public health vector control. PLOS Neglected Tropical Diseases, v. 13, n. 4, p. e0007322, 17 abr. 2019.

LOVEJOY, T. E.; NOBRE, C. Amazon Tipping Point. Science Advances, v. 4, n. 2, p. eaat2340, 1 fev. 2018.

MARICATO, E. Informalidade Urbana no Brasil: a lógica da cidade fraturada. In: WANDERLEY, L. E.; RAICHELIS, R. (Ed.). A cidade de São Paulo, relações internacionais e gestão pública. São Paulo: Educ, 2009. p. 296.

MATSUEDA, M. Predictability of Euro-Russian blocking in summer of 2010. Geophysical Research Letters, v. 38, n. 6, 2011.

MENDES, C. S. et al. Impacto das mudanças climáticas sobre a leishmaniose no Brasil. Ciência \& Saúde Coletiva, v. 21, n. 1, p. 263-272, jan. 2016.

MESSINA, J. P. et al. The current and future global distribution and population at risk of dengue. Nature Microbiology, v. 4, n. 9, p. 1508-1515, set. 2019. 
MILLS, J. N.; GAGE, K. L.; KHAN, A. S. Potential Influence of Climate Change on Vector-Borne and Zoonotic Diseases: a review and proposed research plan. Environmental Health Perspectives, v. 118, n. 11, p. 1507-1514, 1 nov. 2010.

MOO-LLANES, D. A. Nicho ecológico actual y futuro de la Leishmaniasis (Kinetoplastida: Trypanosomatidae) en la región Neotropical. Revista de Biología Tropical, v. 64, n. 3, 1 jul. 2016.

MOSS, R. H. et al. The next generation of scenarios for climate change research and assessment. Nature, v. 463, n. 7.282, p. 747-756, fev. 2010.

NAIMI, B. et al. Where is positional uncertainty a problem for species distribution modelling? Ecography, v. 37, n. 2, p. 191-203, 2014.

NIETO, P.; MALONE, J. B.; BAVIA, M. E. Ecological niche modeling for visceral leishmaniasis in the state of Bahia, Brazil, using genetic algorithm for rule-set prediction and growing degree day-water budget analysis. Geospatial health, v. 1, n. 1, p. 115-126, nov. 2006.

OLIVEIRA-FERREIRA, J. et al. Malaria in Brazil: an overview. Malaria Journal, v. 9, n. 1, p. 115, 30 abr. 2010.

PARHAM, P. E.; MICHAEL, E. Modeling the Effects of Weather and Climate Change on Malaria Transmission. Environmental Health Perspectives, v. 118, n. 5, p. 620-626, 1 maio 2010.

PETERSON, A. Ecologic Niche Modeling and Spatial Patterns of Disease Transmission. Emerging Infectious Diseases, v. 12, n. 12, p. 1822-1826, 2006.

PETERSON, A. T. et al. Ecological Niches and Geographic Distributions. Princeton, N.J.: [s.n.].

PETERSON, A. T. et al. Influences of climate change on the potential distribution of Lutzomyia longipalpis sensu lato (Psychodidae: Phlebotominae). International Journal for Parasitology, v. 47, n. 10, p. 667-674, 1 set. 2017.

PETERSON, A. T.; SOBERÓN, J. Species Distribution Modeling and Ecological Niche Modeling: getting the concepts right. Natureza \& Conservação, v. 10, n. 2, p. 102-107, 2012.

PHILLIPS, S. J.; ANDERSON, R. P.; SCHAPIRE, R. E. Maximum entropy modeling of species geographic distributions. Ecological Modelling, v. 190, n. 3, p. 231-259, 25 jan. 2006.

POSSAS, C. et al. Yellow fever outbreak in Brazil: the puzzle of rapid viral spread and challenges for immunisation. Memórias do Instituto Oswaldo Cruz, v. 113, n. 10, 3 set. 2018.

R CORE TEAM. R: A language and environment for statistical computing. R Foundation for Statistical Computing, Vienna, Austria. Disponível em: <https://www.r-project.org/>. Acesso em: 7 jun. 2008.

RANDIN, C. F. et al. Monitoring biodiversity in the Anthropocene using remote sensing in species distribution models. Remote Sensing of Environment, v. 239, p. 111626, mar. 2020.

RANGEL, E. F. et al. Eco-Epidemiology of American Visceral Leishmaniasis with Particular Reference to Brazil. In: RANGEL, E. F.; SHAW, J. J. (Ed.). Brazilian Sand Flies. Cham: Springer International Publishing, 2018. p. 381-416.

READY, P. D. Leishmaniasis emergence and climate change. Revue Scientifique et Technique (International Office of Epizootics), v. 27, n. 2, p. 399-412, 1 ago. 2008.

RIVAS, G. B. et al. Effects of temperature and photoperiod on daily activity rhythms of Lutzomyia longipalpis (Diptera: Psychodidae). Parasites \& Vectors, v. 7, n. 1, p. 278, 19 jun. 2014.

ROBINE, J.-M. et al. Death toll exceeded 70,000 in Europe during the summer of 2003. Comptes Rendus Biologies. Dossier: nouveautés en cancérogenèse / New developments in carcinogenesis. v. 331, n. 2, p. 171-178, 1 fev. 2008.

RUFINO, R. et al. Surtos de diarreia na Região Nordeste do Brasil em 2013, segundo a mídia e sistemas de informação de saúde - Vigilância de situações climáticas de risco e emergências em saúde. Ciência \& Saúde Coletiva, v. 21, p. 777-788, mar. 2016. 
SALOMÓN, O. D. et al. Lutzomyia longipalpis urbanisation and control. Memórias do Instituto Oswaldo Cruz, v. 110, n. 7, p. 831-846, nov. 2015.

VALDEZ, L. D.; SIBONA, G. J.; CONDAT, C. A. Impact of rainfall on Aedes aegypti populations. Ecological Modelling, v. 385, p. $96-105,10$ out. 2018.

VAN VUUREN, D. P. et al. The representative concentration pathways: an overview. Climatic Change, v. 109, n. 1, p. 5,5 ago. 2011.

VASCONCELOS, P. F. DA C. Yellow fever. Revista da Sociedade Brasileira de Medicina Tropical, v. 36, n. 2, p. 275-293, abr. 2003.

VASCONCELOS, V. V.; PINHO, C. M. DE D. Multivariate Geovisualization of Dengue, Zika and Chikungunya cases in Brazil: a didactic experience. Hygeia - Revista Brasileira de Geografia Médica e da Saúde, v. 13, n. 25, p. 91-106, 28 set. 2017.

WORLD HEALTH ORGANIZATION. World Malaria Report 2019. [S.I.]: World Health Organization, 2019.

YÉ, Y. et al. Effect of meteorological factors on clinical malaria risk among children: an assessment using villagebased meteorological stations and community-based parasitological survey. BMC Public Health, v. 7, n. 1, p. 101, 8 jun. 2007.

ZANLUCA, C. et al. First report of autochthonous transmission of Zika virus in Brazil. Memórias do Instituto Oswaldo Cruz, v. 110, n. 4, p. 569-572, jun. 2015. 